\title{
O CONTROLE EXTERNO DOS CONTRATOS DA ADMINISTRAÇÃO PÚBLICA \\ PELO TRIBUNAL DE CONTAS: ENSAIO SOBRE O MOMENTO DA \\ FISCALIZAÇÃO FINANCEIRA ADOTADO NO BRASIL E EM PORTUGAL
}

\author{
EXTERNAL CONTROL OF PUBLIC ADMINISTRATION PROCUREMENT CONTRACTS BY THE \\ COURT OF AUDITORS: ESSAY ON THE MOMENT OF FINANCIAL SUPERVISION ADOPTED IN
}

BRAZIL AND PORTUGAL

\section{Gilberto Pinto Monteiro Diniz*}

\begin{abstract}
RESUMO: No Brasil e em Portugal, a contratação pública representa uma das principais fontes de despesa pública, constituindo-se, portanto, matéria de elevado grau de relevância e materialidade para a fiscalização financeira a cargo do tribunal de contas. Em razão disso, o objetivo deste trabalho é demonstrar o momento adotado pelos órgãos de controle externo desses dois países para verificar se o procedimento adotado pela Administração Pública para efetivar a contratação pública obedeceu às normas jurídicas pertinentes, bem assim se a execução contratual cumpriu com êxito o objeto pactuado e, ainda, se atingiu o resultado desejado.
\end{abstract}

PALAVRAS-CHAVE: Tribunal de contas; fiscalização financeira; controle prévio, concomitante e subsequente; contratação pública.

\begin{abstract}
In Brazil and Portugal, public procurement represents a major source of public expenditure and thus constitutes a matter of high degree of relevance and materiality for the financial supervision handled by the Court of Auditors. For this reason, the aim of this work is to demonstrate the moment adopted by the external control bodies of these two countries to check if the procedure adopted by the Public Administration to carry out the public procurement abided by the relevant legal norms, as well as if the contract performance successfully fulfilled the agreed subject matter and, also, if it has reached the desired result.
\end{abstract}

KEYWORDS: Court of auditors; financial supervision; prior, concomitant, and subsequent checking; public procurement.

SUMÁRIO: Introdução. 1. Estado democrático de direito e controle externo exercido pelo tribunal de contas. 2. Inserção do tribunal de contas na estrutura do estado. 2.1. No estado brasileiro. 2.2. No estado português. 3. Contratação pública. 3.1. Relevância econômica e financeira da contratação pública. 4. Fiscalização financeira da contratação pública pelo tribunal de contas. 5. Momento da fiscalização financeira da contratação pública: prévio, concomitante e subsequente. 5.1. Momento adotado no Brasil. 5.2. Momento adotado em Portugal. Considerações finais. Referências.

\section{INTRODUÇÃO}

A Administração Pública, cada vez mais, tem utilizado a contratação de particulares para adquirir bens, serviços e realizar obras de variadas espécies, procedimento que, em contrapartida, gera crescente dispêndio de dinheiro público.

Em razão dos vultosos valores envolvidos a cada ano, o que ficará devidamente demonstrado no desenvolver deste trabalho, a contratação pública reveste-se de elevado grau de relevância e materialidade para a efetivação das ações de controle externo a cargo do tribunal de contas, cuja principal atribuição é fiscalizar a gestão pública, a fim de evitar abusos e descontroles no emprego dos escassos recursos públicos.

\footnotetext{
* Universidade Federal de Minas Gerais.
} 


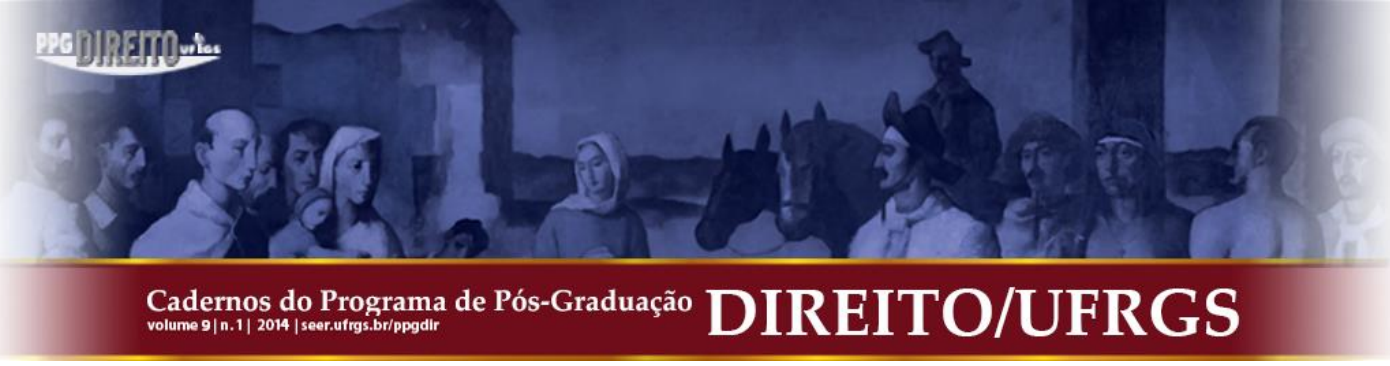

Esses aspectos são suficientes para explicitar a importância e a atualidade do tema proposto, que tem por primeiro objetivo analisar o momento no qual o tribunal de contas efetiva ou pode efetivar, segundo a legislação de regência, a fiscalização financeira da contratação pública.

Para atingir tal desiderato, realizou-se pesquisa bibliográfica da legislação, doutrina e jurisprudência acerca da fiscalização realizada no Brasil, pelo Tribunal de Contas da União TCU -, e em Portugal, pelo Tribunal de Contas português. Optou-se por realizar estudo comparativo porque, embora Brasil e Portugal adotem o sistema de tribunal de contas para exercício da fiscalização da gestão dos bens e recursos públicos, há dessemelhanças entre a estruturação e o momento de atuação das cortes de contas desses dois países, o que agrega relevantes aspectos ao trabalho realizado.

O TCU, por exemplo, é o responsável pelo controle externo da União federal brasileira e constitui-se paradigma para os demais tribunais de contas e conselhos de contas brasileiros, conforme prescreve o art. 75 da Constituição da República.

O Estado unitário ${ }^{1}$ português, por outro lado, tem somente um Tribunal de Contas, sediado em Lisboa, o qual dispõe de três Seções especializadas na Sede e de duas Seções Regionais de competência genérica: uma na Região Autônoma dos Açores e outra na Região Autônoma da Madeira.

Isso demarca dualidade na abrangência do controle externo a cargo dos tribunais de contas brasileiro e português. É que, diversamente do que ocorre em Portugal, no Brasil, além do TCU, existem os tribunais de contas dos Estados-membros, do Distrito Federal, dos Municípios de São Paulo e do Rio de Janeiro e os tribunais de contas dos Municípios da Bahia, de Goiás, do Ceará e do Pará. Essa diferenciação se justifica pelo fato de Portugal ser organizado sob a forma de Estado unitário e o Brasil de federação.

Embora exista tal diferenciação, em virtude da organização político-administrativa adotada pelos respectivos Estados, como também alguma desigualdade no momento da fiscalização, que será explicitada no desenvolver deste artigo, na essência, o tribunal de contas brasileiro, como o português, exerce o controle externo da Administração Pública.

\footnotetext{
${ }^{1}$ Constituição portuguesa. Artigo $6 .^{\circ}$ (Estado unitário) 1. O Estado é unitário e respeita na sua organização e funcionamento o regime autonómico insular e os princípios da subsidiariedade, da autonomia das autarquias locais e da descentralização democrática da administração pública. 2. Os arquipélagos dos Açores e da Madeira constituem regiões autónomas dotadas de estatutos político-administrativos e de órgãos de governo próprio.
} 
democráticos, como Brasil e Portugal, ao tribunal de contas foi outorgado, nas novas ordens jurídicas instauradas, respectivamente, pelas Constituições de $1988^{2}$ e $1976^{3}$, um dos mais proeminentes papéis constitucionais já conferidos às instituições públicas.

Isso se justifica porque, "muito embora este tipo de órgão de controlo financeiro possa existir em quaisquer regimes políticos, visando assegurar a legalidade estabelecida" (TAVARES, 2008, p. 969), o tribunal de contas alcança e assume toda plenitude de organização, atuação, eficácia e eficiência de suas ações no Estado de Direito democrático.

Para Hélio Mileski (2009, p. 103), o tribunal de contas tornou-se o olho do povo, na medida em que verifica se há o regular e legal emprego dos dinheiros públicos e se a sua aplicação está direcionada ao interesse público, constituindo-se, por isso, peça imprescindível do regime democrático.

$\mathrm{Na}$ tessitura do Estado de Direito democrático, então, é possível afirmar que o tribunal de contas, no desencadear do processo construtivo do exercício da cidadania, apresenta-se, tanto no Brasil quanto em Portugal, como ator legitimado para fiscalizar e controlar a gestão pública e, consequentemente, garantir a efetivação de direitos fundamentais dos cidadãos pelo Estado, sob a forma de serviços públicos oportunos e de qualidade, como também prestar informações sobre a gestão pública à sociedade.

\section{INSERÇÃO DO TRIBUNAL DE CONTAS NA ESTRUTURA DO ESTADO}

Nessa esteira de raciocínio, constituindo-se o controle externo da gestão dos bens e recursos públicos meio de limitação do poder político emanado do Estado de Direito, é a Constituição - “ordenação sistemática e racional da comunidade política através de um documento escrito no qual se declaram as liberdades e os direitos e se fixam os limites do poder político" (CANOTILHO, 2000, p. 52) - o diploma jurídico legítimo para prescrever as normas básicas de organização e estruturação do tribunal de contas.

\footnotetext{
${ }^{2}$ Constituição brasileira, Art. $1^{\circ}$. A República Federativa do Brasil, formada pela união indissolúvel dos Estados e Municípios e do Distrito Federal, constitui-se em Estado democrático de direito e tem como fundamentos [...]

${ }^{3}$ Constituição portuguesa, Art. $2^{\circ}$. A República Portuguesa é um Estado democrático, baseado na soberania popular, no respeito e na garantia dos direitos e liberdades fundamentais e no pluralismo de expressão e organização política democrática, que tem por objectivo assegurar a transição para o socialismo mediante a criação de condições para o exercício democrático do poder pelas classes trabalhadoras.
} 


\subsection{No Estado brasileiro}

No Brasil, as normas que prescrevem a função, organização, composição e competências do tribunal de contas estão insertas nos artigos 70, 71, 73 e 75 da Constituição da República de 1988, os quais integram a Seção IX (da fiscalização contábil, financeira e orçamentária), do Capítulo I (do poder legislativo), do Título IV (da organização dos poderes).

Nos termos das disposições contidas nos artigos 70 e 71, a fiscalização contábil, financeira, orçamentária, operacional e patrimonial da União e das entidades da Administração direta e indireta, quanto à legalidade, legitimidade, economicidade, aplicação das subvenções e renúncia de receitas, será exercida pelo Congresso Nacional, mediante controle externo - que será exercido com o auxílio do tribunal de contas -, e pelo sistema de controle interno de cada poder. $\mathrm{O}$ art. $71^{4}$ também estabelece as competências outorgadas ao Tribunal de Contas da União.

A seu turno, o art. 75 estabelece que as normas constitucionais inerentes à fiscalização contábil, financeira e orçamentária aplicam-se, no que couber, à organização, composição e fiscalização dos tribunais e conselhos de contas dos estados e do distrito federal, bem como dos tribunais ou conselhos de contas dos municípios.

A inserção dos preceptivos concernentes à organização e às atribuições do tribunal de contas no Capítulo I do Título IV da Constituição republicana, como também o fato de o caput do art. 71 dispor que o controle externo - a cargo do poder legislativo - será exercido com o auxílio do tribunal de contas, pode conduzir o intérprete menos atento à conclusão de que esse órgão integra a estrutura orgânica do legislativo e de que a ele se subordina hierarquicamente. Conclusão nesse sentido, entretanto, na minha avaliação, constitui nítida miragem jurídica, conforme será demonstrado neste breve trecho.

Em princípio, entendo que a mera interpretação sistemática do próprio texto constitucional basta para esclarecer qualquer possível dúvida a esse respeito. Primeiro, porquanto, de acordo com o caput do art. $44^{5}$, o tribunal de contas não figura entre os órgãos integrantes do legislativo. Segundo, porque não pode ser subordinado órgão que detém

\footnotetext{
4 Art. 71. O controle externo, a cargo do Congresso Nacional, será exercido com o auxílio do Tribunal de Contas da União, ao qual compete:

${ }^{5}$ Art. 44. O Poder Legislativo é exercido pelo Congresso Nacional, que se compõe da Câmara dos Deputados e do Senado Federal.
} 
competência constitucional para fiscalizar aquele que se supõe ser subordinante. Terceiro, porque o tribunal de contas exerce as atribuições que lhe foram conferidas pela Constituição de forma autônoma, sem necessitar da interferência ou autorização do parlamento. Quarto, a ratio essendi do comando constitucional é que o controle externo seja exercido tanto sob o enfoque político, que se materializará no âmbito do legislativo, que é composto pelos representantes do povo, verdadeiro titular dos bens e recursos públicos, como sob o viés técnico-especializado, que se efetivará pelo tribunal de contas.

Em verdade, a relação entre legislativo e tribunal de contas é de cooperação ou colaboração, na acepção de operação conjunta e concertada. Nesse sentido, basta verificar, por exemplo, que o legislativo não exerce a sua principal atribuição inerente à função de controle externo - julgar as contas do chefe do executivo (CF/88, art. 49, X) - sem o necessário e indispensável parecer prévio, peça opinativa técnico-jurídica, sobre essas contas, cuja competência constitucional para emiti-lo é da corte de contas. Essa relação de cooperação ou colaboração estende-se às demais funções do estado - utilizando-se da apropriada expressão de Florivaldo Dutra de Araújo $^{6}$ (2011, p. 29-30) -, na medida em que, da fiscalização levada a efeito pelo tribunal de contas, emanam recomendações e determinações que servem para aprimorar a gestão dos órgãos e entidades que as integram.

A afirmativa de que o tribunal de contas, no Brasil, não integra e não é subordinado à função legislativa tem lastro na doutrina pátria mais abalizada sobre a matéria. Confira-se, a lição de Carlos Ayres Britto, Ministro aposentado do Supremo Tribunal Federal, litteris:

[...] além de não ser órgão do Poder Legislativo, o Tribunal de Contas da União não é órgão auxiliar do Parlamento Nacional, naquele sentido de inferioridade hierárquica ou subalternidade funcional. Como salta à evidência, é preciso medir com a trena da Constituição a estatura de certos órgãos públicos para se saber até que ponto eles se põem como instituições autônomas e o fato é que o TCU desfruta desse altaneiro status normativo da autonomia. Donde o acréscimo de idéia que estou a fazer: quando a Constituição diz que o Congresso Nacional exercerá o controle externo "com o auxílio do Tribunal de Contas da União" (art. 71), tenho como certo que está a falar de "auxílio" do mesmo modo como a Constituição fala do Ministério Público perante o Poder Judiciário. Quero dizer: não se pode exercer a jurisdição senão com a participação do Ministério Público. Senão com a obrigatória

\footnotetext{
${ }^{6} \mathrm{O}$ poder do estado manifesta-se pelo exercício de variadas atividades, que podem ser classificadas por suas características fundamentais. A mais conhecida e importante classificação - sobretudo por seus efeitos práticos na organização do estado - é a que tipifica tais atividades em legislativas, administrativas e jurisdicionais. [...] Fala-se, pois, em função legislativa, função administrativa (ou executiva) e função jurisdicional. Mais comum, no entanto, é o emprego da expressão 'poderes do estado', em vez de funções. A rigor, trata-se de terminologia inadequada, pois o poder do estado é uno e indivisível, implicando, porém, como já registrado, o desenvolvimento de diversas atividades, agrupáveis nas três funções mencionadas.
} 


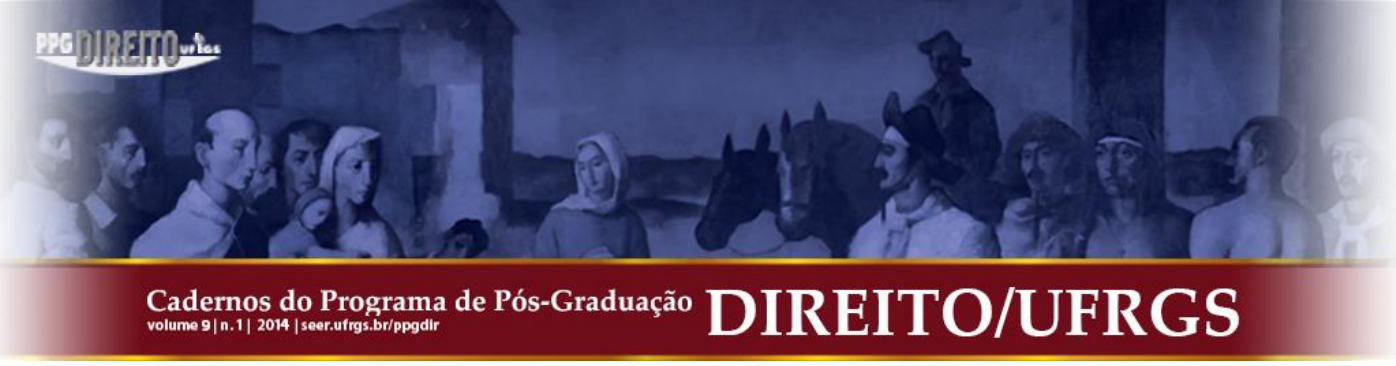

participação ou o compulsório auxílio do Ministério Público. Uma só função (a jurisdicional), com dois diferenciados órgãos a servi-la. Sem que se possa falar de superioridade de um perante o outro. 3.2. As proposições se encaixam. Não sendo órgão do Poder Legislativo, nenhum Tribunal de Contas opera no campo da subalterna auxiliaridade. Tanto assim que parte das competências que a Magna Lei confere ao Tribunal de Contas da União nem passa pelo crivo do Congresso Nacional ou de qualquer das Casas Legislativas Federais (bastando citar os incisos III, VI e IX do art. 71). O TCU se posta é como órgão da pessoa jurídica União, diretamente, sem pertencer a nenhum dos três Poderes Federais. Exatamente como sucede com o Ministério Público, na legenda do art. 128 da Constituição, incisos I e II. (BRITTO, 2005, p. 62).

No mesmo sentido é o magistério de Celso Antônio Bandeira de Mello (2009, p. 70): “[...] sobre o enquadramento constitucional do Tribunal de Contas, não há senão responder que o Texto Constitucional houve por bem delineá-lo como órgão autônomo, não enquadrado nem no Executivo, nem no Legislativo, nem no Judiciário".

Igualmente, Diogo de Figueiredo Moreira Neto assim se posiciona sobre o tema:

No Brasil, a Carta Política de 1988 instituiu o Tribunal de Contas da União, como padrão para os órgãos congêneres estaduais e municipais (art. 75), gozando das mesmas prerrogativas de autonomia constitucional asseguradas aos tribunais do Judiciário (art. 73, in fine, c/c art. 96) de modo que, de maneira enfática, no elenco de suas atribuições constitucionalmente dispostas, satisfaz concomitantemente a todos os critérios que igualmente o identificam e o distinguem como uma das estruturas políticas da soberania, no desempenho de diversas funções de proteção de direitos fundamentais de sede constitucional. (MOREIRA NETO, 2005, p. 104)

Mesmo diante de tão alentados argumentos, muitos intérpretes, ainda presos à tradicional separação tripartite dos Poderes, ou funções, do Estado, ainda tentam forçar exegeses tendentes a incluir o tribunal de contas na estrutura do legislativo. Esquecem-se esses intérpretes que, na atualidade, ganha dimensão e acolhimento o fenômeno do "policentrismo institucional" citado por Moreira Neto (2005, p. 101), que implica, em linhas gerais, o alargamento das funções constitucionais a órgãos autônomos subordinantes, como são, por exemplo, o tribunal de contas e o ministério público.

Ainda de acordo com Moreira Neto:

(...) a estruturação do poder do Estado é historicamente dinâmica, pois segue a linha da contenção de monopólios e oligopólios do poder político, uma providencial garantia da sociedade contra os males que semearam em um passado ainda muito próximo.

Assim, o processo organizativo do poder está longe de se ter esgotado no moderno constitucionalismo, e vai prosseguindo, a destacar novas funções específicas, que passam a ser desempenhadas por órgãos, mas que não mais se incluem nos três complexos orgânicos que são denominados, por metonímia tradicional, de Poderes, 


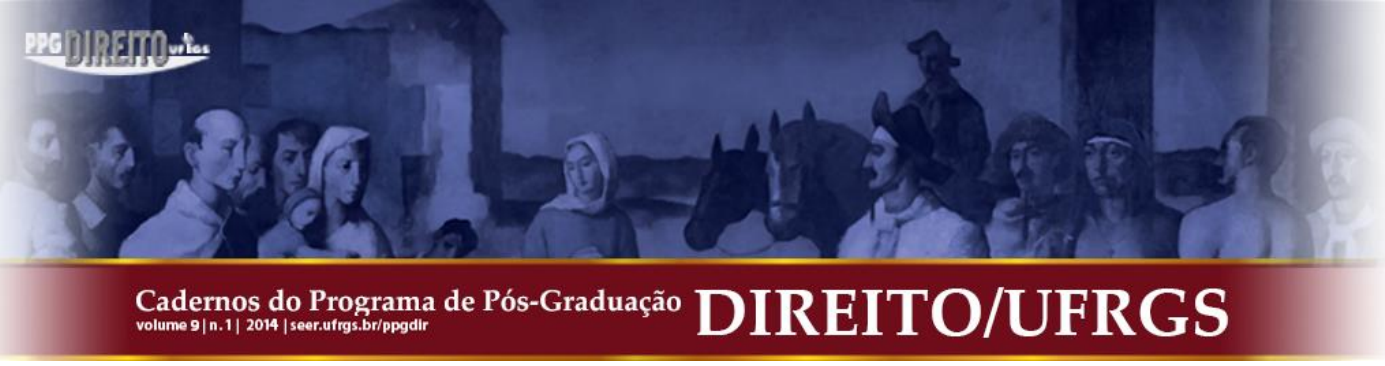

porque exercem o que eram antes as únicas, mas hoje restam apenas como as mais importantes, segmentações do Poder do Estado (ou "Poderes da União", como está no art. $\left.2^{\circ}, \mathrm{CF}\right)$.

São nítido exemplo desse fenômeno, na ordem jurídica brasileira, os Tribunais de Contas, de que se ocupa este Parecer, mas também o são as Funções Essenciais à Justiça, com ênfase no complexo orgânico do Ministério Público, a que se acrescem os conselhos profissionais, depois de sua recente transformação, em rol que pode ser ainda ampliado, como já ocorre em outros países, com a inclusão constitucional de novos órgãos aos quais se cometam funções estatais, cuja autonomia leve ao aprimoramento do controle e da democracia, como poderão sê-lo, por exemplo, um Ombudsman ou um Banco Central independente.

"Esta evolução", conclui NUNO PIÇARRA, para bem encerrar com sua arguta síntese o que se procurou elucidar neste item, "está, aliás, em consonância com a progressiva transição de um método abstrato-dedutivo para um método normativoconcreto na abordagem e no tratamento dogmático do princípio da separação dos poderes. Ele tende hoje a construir-se a partir da ordenação de competências constitucionais concreta."

As disposições constitucionais em exame geram, ainda, controvérsia a respeito de o tribunal de contas ter, ou não, jurisdição, na acepção técnica de prerrogativa para dizer o direito. Sobre essa questão, de início, observa-se que a Constituição é expressa ao estatuir que o TCU tem jurisdição em todo o território nacional (art. 73), ou seja, o poder-dever de fiscalizar a gestão pública atribuído ao TCU abrange todos os órgãos e entidades que gerenciem, administrem ou se utilizem de dinheiros, bens e recursos públicos federais. Lado outro, não se pode olvidar que a jurisdição, na acepção técnica, é função do Estado que foi cometida, com preponderância, ao Judiciário. Isso, no entanto, não impede que a Constituição outorgue, excepcionalmente, parcela dessa função a outros órgãos, como de fato fez. Ao senado federal, por exemplo, foi atribuída competência privativa para julgar o presidente da república e outros agentes públicos $\left(\mathrm{CF}\right.$, art. 52, I e $\left.\mathrm{II}^{7}\right)$. E, ao tribunal de contas, a Constituição, além das outras atribuições que explicita, conferiu a de julgar as contas dos administradores e demais responsáveis por dinheiros, bens e valores públicos, bem como daqueles que derem causa a perda, extravio ou outra irregularidade de que resulte prejuízo ao erário $(\mathrm{CF}$, art. 71, II).

De tudo isso é possível inferir que o tribunal de contas tem jurisdição, não aquela própria do Judiciário, mas que pode ser entendida como jurisdição de controle financeiro de contas, consubstanciada no poder-dever de dizer, revelar ou aplicar o direito - sobretudo

\footnotetext{
${ }^{7}$ Art. 52. Compete privativamente ao Senado Federal: I - processar e julgar o Presidente e o Vice-Presidente da República nos crimes de responsabilidade, bem como os Ministros de Estado e os Comandantes da Marinha, do Exército e da Aeronáutica nos crimes da mesma natureza conexos com aqueles; II processar e julgar os Ministros do Supremo Tribunal Federal, os membros do Conselho Nacional de Justiça e do Conselho Nacional do Ministério Público, o Procurador-Geral da República e o Advogado-Geral da União nos crimes de responsabilidade.
} 


\section{vay)}

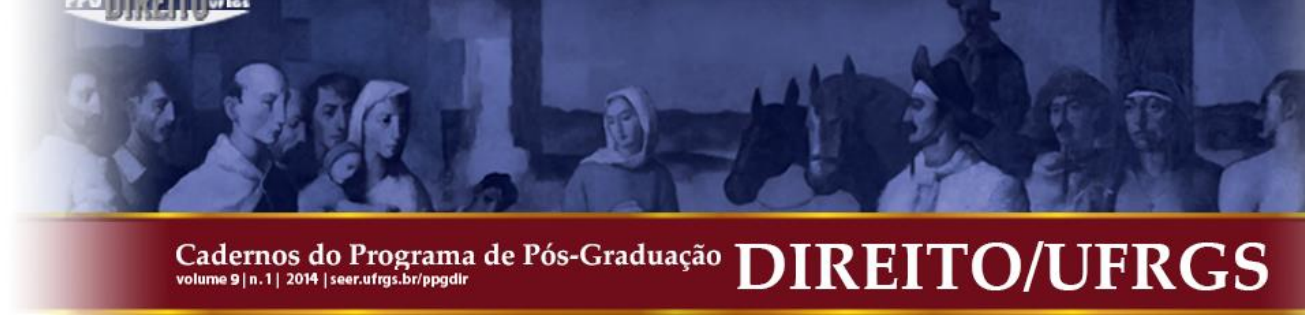

normas de direito financeiro e de finanças públicas -, no exame material das contas públicas que a Constituição lhe reservou expressamente a competência de julgamento. Isso não retira a prerrogativa do Judiciário de rever, se provocado por algum interessado, a decisão sobre essas contas (CF, art. $5^{\circ}, \mathrm{XXXV)}$. A revisão judicial, entretanto, deve limitar-se a verificar possível inobservância de formalidades legais na instrução processual ou na realização do julgamento. Não pode o Judiciário, a meu juízo, rever o conteúdo da decisão, pois o julgamento de mérito sobre tais contas a Constituição reservou, expressamente, ao tribunal de contas.

Sobre esse ponto, julgado da Terceira Turma do Tribunal Regional Federal da $4^{\mathrm{a}}$ Região, datado de 03/12/2002, no Agravo de Instrumento AG 19240 SC 2002.04.01.0192400, de relatoria do Desembargador Federal Carlos Eduardo Thompson Flores Lenz, fundamentado na jurisprudência do Supremo Tribunal Federal e do Superior Tribunal de Justiça, assenta que não é possível o reexame, na via judicial, de contas julgadas pelo tribunal de contas, a não ser quanto ao seu aspecto formal ou tisna de ilegalidade manifesta.

Não se pode deixar de mencionar, todavia, que o Judiciário, em alguns arestos, entende que pode analisar o mérito de decisões das cortes de contas, com base no princípio da inafastabilidade da tutela jurisdicional, mesmo inexistindo vício claro, como se verifica no julgamento, pela Primeira Turma do Tribunal Regional da $5^{\text {a }}$ Região, da Apelação Cível: AC 380126 PE 2005.83.02.000431-8, de relatoria do Desembargador Federal Élio Wanderley de Siqueira Filho (Substituto), em 11/07/2007.

Essa linha de argumentação, entretanto, não me convence. Com efeito, o tribunal de contas é o órgão constitucionalmente legitimado para fazer o julgamento das contas referidas no inciso II do art. 71, tanto que aos Ministros do TCU, os julgadores, a Constituição conferiu as mesmas garantias, prerrogativas, impedimentos, vencimentos e vantagens dos Ministros do Superior Tribunal de Justiça $\left(\mathrm{CF} / 88\right.$, art. $\left.73, \S 3^{\circ}\right)$. Além do mais, o tribunal de contas tem expertise necessária e corpo técnico altamente especializado para realizar essa atribuição constitucional. É dizer, a Constituição criou magistratura especializada (magistratura de contas) para julgar as contas dos administradores e demais responsáveis por dinheiros, bens e valores públicos, bem como as daqueles que ocasionarem perda, extravio ou dano ao erário.

Afinal, para corroborar a conclusão de que o mérito do julgamento das contas públicas feito pelo tribunal de contas é insindicável ao Judiciário, não é demasia relembrar clássica, inexcedível e ainda atual lição de Pontes de Miranda, na qual o inolvidável mestre pontifica que, "Desde 1934, a função de julgar as contas está claríssima, no texto 


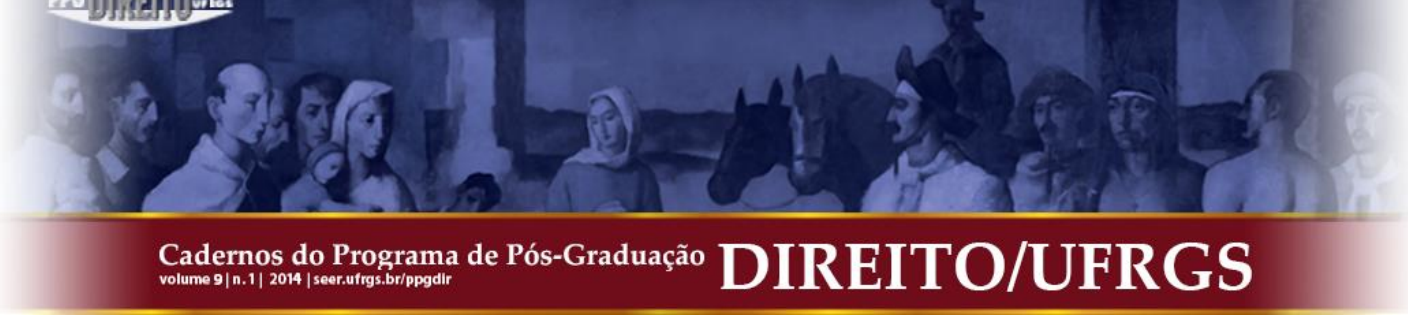

constitucional. Não havemos de interpretar que o Tribunal de Contas julgue e outro juiz as rejulgue depois. Tratar-se-ia de absurdo bis in idem. Ou o tribunal julga ou não julga (...)”.

Da intelecção das normas constitucionais brasileiras e com fundamento na doutrina citada, conclui-se que o tribunal de contas é órgão autônomo técnico-especializado de extração constitucional e que detém parcela da função jurisdicional do Estado, especificamente para julgar as contas dos administradores públicos e demais responsáveis por dinheiros, bens e recursos públicos. Trata-se, portanto, de órgão que se insere na estrutura organizacional do Estado brasileiro, não se integrando na organização formal de nenhuma das três funções (ou Poderes) do Estado [legislativa, administrativa (ou executiva), ou judiciária].

\subsection{No Estado português}

De forma bem menos analítica que a brasileira, sobretudo relativamente à definição das competências, a Constituição portuguesa de 1976, com as alterações introduzidas pela Revisão Constitucional de 2005, traz a lume as normas acerca da organização e estrutura básica do tribunal de contas nos artigos $110^{8}, 202^{9}, 209^{10}$ e $214^{11}$, esses três últimos dispositivos insertos no Título $\mathrm{V}$, que estabelece as normas sobre os tribunais portugueses.

De acordo com a normatização constitucional, o tribunal de contas está incluído no rol dos tribunais portugueses. A corte de contas, assim como os demais tribunais de Portugal, é qualificada como órgão de soberania e lhe são reconhecidos e destinados os princípios

\footnotetext{
${ }^{8}$ Constituição portuguesa - Artigo $110 .^{\circ}$ (Órgãos de soberania) 1. São órgãos de soberania o Presidente da República, a Assembleia da República, o Governo e os Tribunais.

${ }^{9}$ Constituição portuguesa - Artigo $202 .^{\circ}$ (Função jurisdicional) 1. Os tribunais são os órgãos de soberania com competência para administrar a justiça em nome do povo.

${ }^{10}$ Constituição portuguesa - Artigo 209 ${ }^{\circ}$. (Categorias de Tribunais) 1. Além do Tribunal Constitucional, existem as seguintes categorias de tribunais: a) O Supremo Tribunal de Justiça e os tribunais judiciais de primeira e de segunda instância; $b$ ) O Supremo Tribunal Administrativo e os demais tribunais administrativos e fiscais; c) $\mathrm{O}$ Tribunal de Contas. 2. Podem existir tribunais marítimos, tribunais arbitrais e julgados de paz. 3. A lei determina os casos e as formas em que os tribunais previstos nos números anteriores se podem constituir, separada ou conjuntamente, em tribunais de conflitos. 4. Sem prejuízo do disposto quanto aos tribunais militares, é proibida a existência de tribunais com competência exclusiva para o julgamento de certas categorias de crimes.

${ }^{11}$ Constituição portuguesa - Artigo $214 .^{\circ}$ (Tribunal de Contas) 1. O Tribunal de Contas é o órgão supremo de fiscalização da legalidade das despesas públicas e de julgamento das contas que a lei mandar submeter-lhe, competindo-lhe, nomeadamente: $a$ ) Dar parecer sobre a Conta Geral do Estado, incluindo a da segurança social; b) Dar parecer sobre as contas das Regiões Autónomas dos Açores e da Madeira; $c$ ) Efectivar a responsabilidade por infracções financeiras, nos termos da lei; $d$ ) Exercer as demais competências que lhe forem atribuídas por lei. 2. O mandato do Presidente do Tribunal de Contas tem a duração de quatro anos, sem prejuízo do disposto na alínea $\mathrm{m}$ ) do artigo $133 .^{\circ}$. 3. O Tribunal de Contas pode funcionar descentralizadamente, por secções regionais, nos termos da lei. 4. Nas Regiões Autónomas dos Açores e da Madeira há secções do Tribunal de Contas com competência plena em razão da matéria na respectiva região, nos termos da lei.
} 


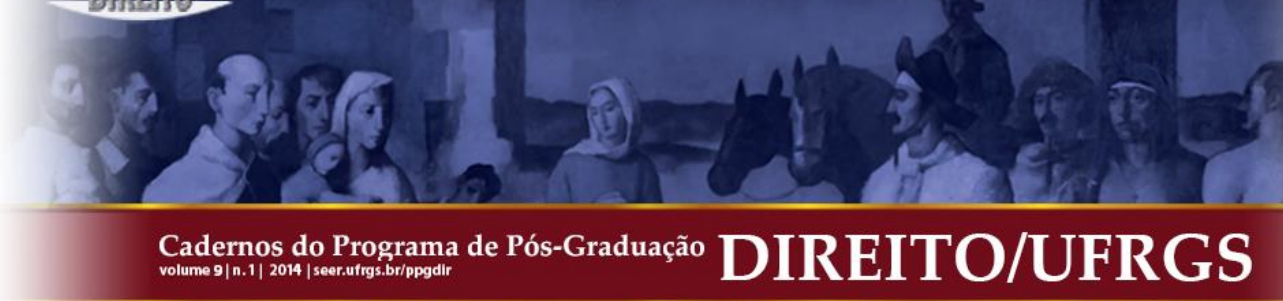

gerais constitucionalmente prescritos para os tribunais judiciais, consoante o disposto nos mencionados artigos 110 (número 1) e 202 (número 1). O art. 214, a seu turno, estatui que "o Tribunal de Contas é o órgão supremo de fiscalização da legalidade das despesas públicas e de julgamento das contas que a lei mandar submeter-lhe [...]".

José Fernandes Farinha Tavares assim se pronunciou sobre o estatuto, natureza e inserção do tribunal de contas na estrutura do Estado português:

[...] o Tribunal de Contas é, estrutural e funcionalmente, um tribunal, mais propriamente, um tribunal financeiro, um órgão de soberania, um órgão constitucional do Estado, independente, não inserido na Administração Pública, em particular, no Estado/Administração. É um órgão externo relativamente à Administração Pública, constituindo esta a sua área privilegiada, embora não exclusiva, de actuação ou de controlo [...].

Concluindo, o Tribunal de Contas é um «órgão de soberania, tribunal supremo, único na sua ordem/categoria, constituindo, em síntese, o órgão supremo de controlo externo e independente da actividade financeira, nos domínios das receitas, das despesas e do património públicos, podendo, complementarmente, julgar a responsabilidade financeira» 45. Ao apreciarmos, seguidamente, a jurisdição, as atribuições e a competência do Tribunal de Contas, densificaremos, naturalmente, as afirmações que agora produzimos, salientando que o Tribunal exerce várias funções, incluindo a função jurisdicional. (TAVARES, 2007, pp. 39-40).

Também a respeito desse tema e na mesma esteira do pronunciamento anteriormente colacionado, Márcia Vala e Manuel Freire Barros (1997, p. 85) asseveram que:

\begin{abstract}
Na generalidade, o TC é configurado como um verdadeiro Tribunal e integrado no elenco das categorias de tribunais existentes. Como tal, é um órgão de soberania e está sujeito ao estatuto constitucional dos Tribunais. Em suma: o TC é um órgão de soberania, configurado como um órgão independente do Estado, não integrado na Administração Pública. Na especialidade, o TC é caracterizado na dupla vertente de órgão supremo de controlo das finanças públicas e de tribunal financeiro e a sua orgânica encontra-se na Lei no 86/89, de 8 de setembro.
\end{abstract}

A Constituição portuguesa, comparada à brasileira, é bem mais explícita no que tange à organização, natureza e inserção do tribunal de contas na estrutura do Estado, pelo fato de inclui-lo no rol dos tribunais de Portugal, aos quais é outorgada a condição de órgãos de soberania, juntamente com o presidente, o governo e a assembleia nacional.

A explicitude do texto constitucional português, ao tratar do tribunal de contas, não dá margem para dúvidas, como as que ocorrem em relação ao tribunal de contas brasileiro e que foram analisadas no item precedente. Nada obstante, alguns autores, de forma equivocada, dizem que o tribunal de contas português integra o Poder Judiciário. 
Em verdade, de acordo com a Constituição de Portugal, a corte de contas portuguesa tem poder jurisdicional (jurisdição financeira), mas isso não significa que ela integra o Poder Judiciário daquele país. Canotilho (2000, pp. 660-661) deixa isso bastante claro, ao distinguir os conceitos de "Poder Jurisdicional" e "Poder Judiciário". Segundo o citado professor da Faculdade de Direito de Coimbra:

Este conceito - poder jurisdicional - é vulgarmente identificado com 'poder judicial' ou com 'poder judiciário'. Convém dar-lhe um conceito autónomo e útil: poder jurisdicional é o conjunto de magistrados (ordinários, administrativos, fiscais, constitucionais) a quem é confiada a função jurisdicional.

Lado outro, Canotilho diz que o conceito de Poder Judiciário é mais limitado que o anterior, por se restringir ao complexo organizativo da chamada "magistratura ordinária" ou "magistratura comum", sendo que os outros tribunais com competências expressamente circunscritas a determinadas matérias, como, por exemplo, os tribunais administrativos e o tribunal constitucional, incluir-se-iam no Poder Jurisdicional e, não, no Poder Judiciário.

Dos conceitos apresentados, percebe-se que Portugal não adotou o princípio da unidade de jurisdição ou preponderância jurisdicional do Poder Judiciário, como ocorre no Brasil, pois naquele país, conforme afirma Canotilho ${ }^{12}$ (2000, p. 662), há vários tribunais supremos (Supremo Tribunal de Justiça, Supremo Tribunal Administrativo, Tribunal Constitucional, Tribunal de Contas). Todavia, em linhas gerais, a concepção de jurisdição (jurisdictio, jus dicere) tem sentido material e territorial semelhante no Brasil e em Portugal.

Isso também fica bastante claro neste trecho do trabalho intitulado "O Tribunal de Contas de Portugal - Evolução e situação atual”, de autoria de António L. de Souza Franco e Manuel Freire de Barros:

O tribunal tem por missão constitucional ou por atribuições a fiscalização da legalidade financeira e o julgamento das contas públicas (art. $216^{\circ}$ da CRP). Tais atribuições são realizadas através de uma jurisdição própria que abrange, no âmbito

12 O poder jurisdicional pode estruturar-se com base em dois princípios opostos: o princípio da unidade de jurisdição e o princípio da pluralidade. Existe princípio da unidade quando se verifica uma concentração da função de julgar numa única organização judiciária. Consagra-se o princípio da pluralidade de jurisdições quando as funções judiciais são atribuídas a vários órgãos enquadrados em jurisdições diferenciadas e independentes entre si. A Constituição, embora consagre um tendencial pólo de atracção em torno de magistratura ordinária, não adoptou o figurino do princípio da unidade de jurisdição. Depois da revisão de 1989 , ficou claro que ao lado da magistratura ordinária existe uma magistratura administrativa e fiscal e uma magistratura constitucional com órgãos e funções independentes da magistratura ordinária. Desta forma, não existe, entre nós, um "tribunal supremo", mas vários tribunais supremos (Supremo Tribunal de Justiça, Supremo Tribunal Administrativo, Tribunal Constitucional, Tribunal de Contas). 


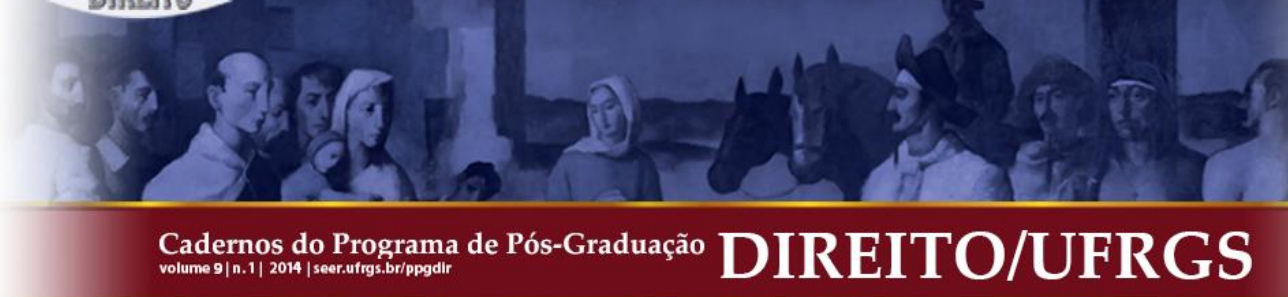

material (lato sensu), o poder de controlo financeiro em toda a ordem jurídica portuguesa, no âmbito territorial, todo o território nacional e o estrangeiro, e no âmbito pessoal, em geral, todas as entidades que administram dinheiros públicos (independentemente da sua natureza jurídica) e, em especial, os serviços e organismos que integram a Administração Pública - central, regional e local autárquica $\left(\operatorname{artigos} 1^{\circ}\right.$ e $17^{\circ}$ ) -, excepto as empresas públicas.

Por tudo o que foi expendido nesta seção, é possível concluir que o tribunal de contas português é órgão de soberania, de matriz constitucional, independente, técnico-especializado, que detém jurisdição financeira e que se integra à estrutura do Estado português e, não, ao arcabouço organizacional das tradicionais funções (ou órgãos) do Estado.

\section{CONTRATAÇÃO PÚBLICA}

Nesse contexto, tanto no Brasil como em Portugal, dois Estados de Direito democráticos, o tribunal de contas é órgão constitucional autônomo e lhe são outorgadas competências para exercer, sob o enfoque técnico-especializado, a nobre e relevante função de controle externo da gestão dos bens e recursos públicos.

Entre as competências cometidas ao tribunal de contas, com efeito, inclui-se a fiscalização da contratação pública, forma de expressão da administração consensual (OLIVEIRA E SCHWANKA, 2008), por meio da qual a Administração Pública busca o consensualismo e a cooperação nas relações com o particular ou administrado. Jacques Chevallier refere-se à contratualização como nova técnica de governança, neste excerto:

[...] a contratualização aparece emblemática dessas novas técnicas de 'governança', que são chamadas a tomar o lugar dos antigos métodos de 'governo', de tipo unilateral e coercitivo: a ação pública torna-se o produto de interações entre atores múltiplos, públicos e privados, quanto aos quais se procura conciliar as estratégias e harmonizar os interesses; o contrato é o meio de formalizar essa cooperação. (CHEVALLIER, 2009, p. 163).

Enzo Roppo também entende como salutar a opção pela contratualização, em detrimento do ato impositivo ou unilateral, porque "a procura e a promoção do 'consenso' dos 'administrados' significam desenvolvimento de sua activa e consciente 'participação', na qual, por sua vez, se encontra um pressuposto de democracia e, ao mesmo tempo, de eficiência do procedimento administrativo" (ROPPO, 2009, pp. 346-347).

Marçal Justen Filho assim se manifesta sobre o consensualismo no âmbito da Administração Púbica: 
A utilização do contrato administrativo se insere num processo político de consensualização do desempenho dos poderes políticos. Embora mantenha a competência para a prática de atos unilaterais e vinculantes perante terceiros, o Estado passa a se valer de institutos jurídicos de natureza consensual. Ao invés de impor unilateralmente aos particulares deveres e obrigações, o Estado recorre ao consenso. Essa solução amplia a legitimidade do poder estatal e reduz conflitos. (JUSTEN FILHO, 2012, p. 12)

Tudo isso demonstra - sem adentrar na origem histórica e nas tensões existentes sobre o contrato administrativo e o contrato privado da Administração Pública, pelo fato de essas questões não interessarem ao objeto deste trabalho -, que a evolução dos tempos altera a realidade e, consequentemente, os fatos do cotidiano, deixando claro que o contrato, seja na seara privada ou pública, atravessa a linha do tempo, adaptando-se às vicissitudes sociais, jurídicas e econômicas para continuar sendo instrumento essencial da vida em sociedade.

É fato, portanto, que a Administração Pública se vale, cada vez mais, desse vetusto e tradicional instituto jurídico e fonte geradora de obrigações, uma vez que, para atender às demandas sempre crescentes da sociedade, aumenta o volume de contratações com particulares, máxime para adquirir bens e serviços, para a consecução de seus fins que, em ultima ratio, é o interesse público primário, ou seja, de toda a coletividade.

\subsection{Relevância econômica e financeira da contratação pública}

Nessa ordem de ideias, a contratação pública constitui-se em relevante instrumento de movimentação econômica e financeira no Estado contemporâneo, considerando que propicia a aquisição, modificação ou extinção de direitos e a assunção de obrigações de dar, fazer e não fazer entre os contratantes, o que resulta, não raro, na circulação de bens, serviços e dinheiro.

Segundo se depreende dos ensinamentos de Enzo Roppo (2009, p. 11), contrato "é a veste jurídico-formal de operações económicas", constituindo-se em expressão maior da livre iniciativa e em um dos mais perfeitos instrumentos de circulação de riqueza.

Ainda nas palavras do citado mestre da Universidade de Gênova:

Muito simplesmente, pode dizer-se que existe operação económica - e portanto possível matéria de contrato - onde existe circulação da riqueza, actual ou potencial transferência de riqueza de um sujeito para outro (naturalmente, falando de 'riqueza' não nos referimos só ao dinheiro e aos outros bens materiais, mas consideramos 


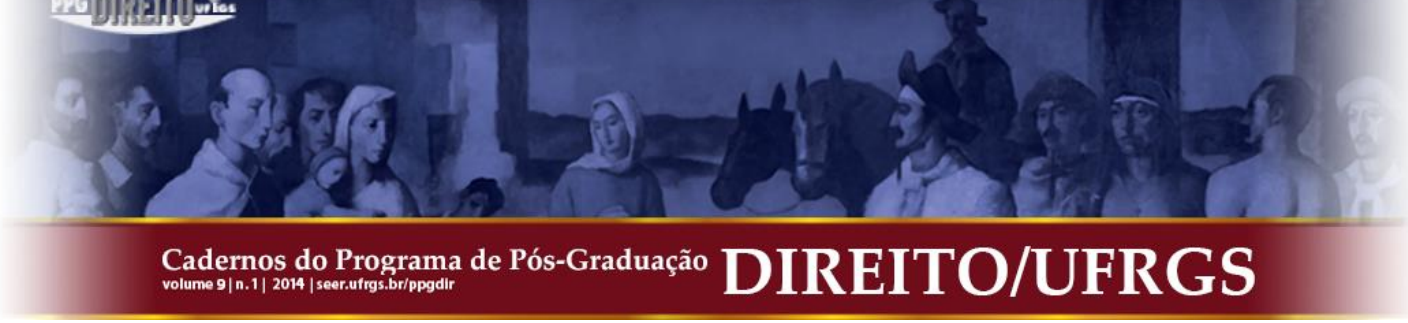

todas as 'utilidades' susceptíveis de avaliação econômica, ainda que não sejam 'coisas' em sentido próprio: nestes termos, até a promessa de fazer ou de não fazer qualquer coisa em benefício de alguém, representa, para o promissário, uma riqueza verdadeira e própria como adiante melhor se verá ).

[...] Isto significa, justamente, por outras palavras, que aquele que celebra um contrato, bem pode prosseguir, subjectivamente, um interesse não económico (mas sim ideal, moral, cultural), sendo certo que o resultado objectivo do contrato deve, ao invés, consistir na obrigação de fazer ou dar qualquer coisa susceptível de expressão pecuniária, segundo os valores do mercado, e, portanto, numa qualquer forma de circulação de riqueza, em suma numa operação económica. (ROPPO, 2009, p. 13)

Gaspar Ariño Ortiz também deixa estreme de dúvida a importância econômica e financeira da contratualização pública, quando afirma:

[...] un Estado social sobre el que descansa el bienestar de los ciudadanos, la 'procura de su existencia', que decía FORSTHOFF, necesita contar con el concurso de la iniciativa privada para la provisión de bienes y servicios, para sí o para los ciudadanos. Entonces acude al contrato. [...] En principio, la actuación unilateral parece más ventajosa que la vinculación del contrato, pero ello exige um Estado flerte, dotado de capacidade de actuación, de una burocracia sólida y de medios económicos suficientes (como eran Alemania o Gran Bretaña a finales del XIX, donde el contrato público nunca llegó a cristalizar). Por el contrario, un Estado débil y una Administración endeudada tendrán que acudir al contrato para la realización de esas obras y servicios (como le ocurrió a España y, en parte, a Francia en los siglos XIX y XX). También los Estados Unidos - que han abominado siempre de las empresas públicas - han gestionado los servicios públicos a través de empresas privadas y, para ello, han tenido que acudir a una figura de contrato progresivamente publificada, como puse de manifiesto hace años. (ORTIZ, 2007, p. 86)

O contrato, mesmo aquele celebrado com ou pela Administração Pública, constituise, em verdade, na mais utilizada fonte de direito e obrigação, que pode ser traduzida como o vínculo de direito por meio do qual um sujeito passivo, intitulado devedor, se compromete a dar, fazer ou não fazer determinada prestação a um sujeito ativo, chamado credor.

No Brasil ${ }^{13}$ e em Portugal $^{14}$, a lei formulou conceito de contrato administrativo de maneira ampla, de modo a abarcar todo e qualquer ajuste entre órgão ou entidade pública e particular, por meio do qual se crie vínculo jurídico entre os contratantes e se estabeleçam obrigações recíprocas, independentemente do nomen iuris que se lhe atribuam as partes.

\footnotetext{
${ }^{13}$ Lei $\mathrm{n}^{\circ}$ 8.666, de 1993 - Art. $2^{\circ}$ [...] Parágrafo único. Para os fins desta Lei, considera-se contrato todo e qualquer ajuste entre órgãos ou entidades da Administração Pública e particulares, em que haja um acordo de vontades para a formação de vínculo e a estipulação de obrigações recíprocas, seja qual for a denominação utilizada.

${ }^{14}$ Decreto-Lei no 57, de 1999 (Código do Procedimento Administrativo) - Art. 165 - 1. Diz-se contrato administrativo o acordo de vontades pelo qual é constituída, modificada ou extinta uma relação jurídica administrativa.
} 


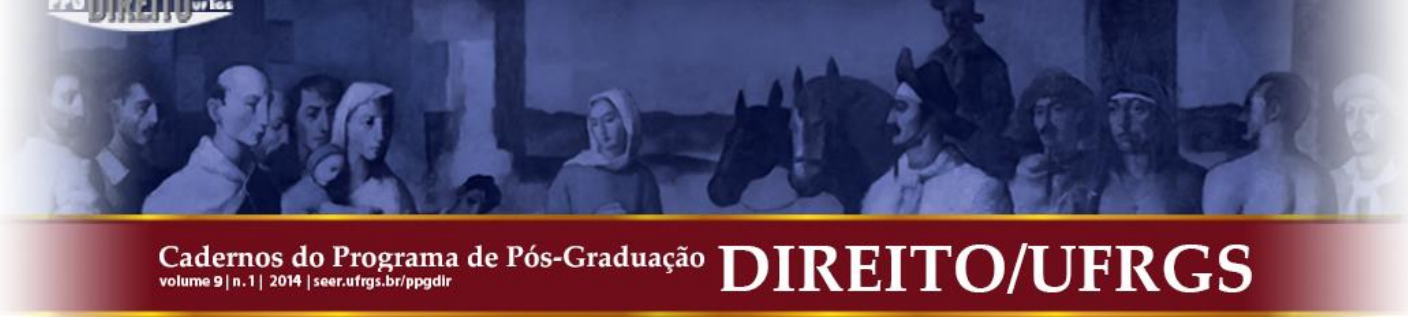

por qualquer cidadão, partido político, associação ou sindicato (art. $74, \S 2^{\circ}$ da $C F$ ), ou por provocação dos órgãos de controle interno (art. 74, IV e $\S 1^{\circ}$ da CF).

No âmbito infraconstitucional, o caput do art. 113 da Lei no 8.666, de 1993, Lei Nacional de Licitações e Contratos Administrativos ${ }^{20}$, bem como o inciso II do art. $1^{\mathrm{o}}$ e seu $\S$ $1^{\circ}$ da Lei $n^{\circ} 8.443$, de 1992, Lei Orgânica do Tribunal de Contas da União ${ }^{21}$, conferem competência ao tribunal de contas para fiscalização da contratação da Administração Pública.

Ainda segundo Ferraz (2009, p. 140), o controle a que se refere o mencionado dispositivo do Estatuto das Licitações é abrangente, ao englobar licitações, contratos de quaisquer naturezas (públicos e semipúblicos - art. 62, $\S 3^{\circ}$ ) e demais instrumentos regidos pelo aludido diploma, $v$. g., convênios, conforme disciplina contida no art. 116, e pode ser realizado mediante representação $\left(\S 1^{\circ}\right)$ ou de ofício $\left(\S 2^{\circ}\right)$.

A representação prevista no $\S 1^{\circ}$ do art. 113 da Lei $n^{\circ} 8.666$, de 1993, nada mais é do que a instrumentalização, nessa seara, do direito previsto no $\S 2^{\circ}$ do art. 74 da Constituição da República, que garante ao cidadão, partido político, associação ou sindicato denunciar irregularidades ou ilegalidades na gestão pública, a fim de evitar malversação dos recursos públicos, cuja titularidade, repita-se, é da sociedade. A possibilidade de controle social, decerto, não pode ser relegada num Estado de Direito democrático.

$\mathrm{O}$ arcabouço normativo brasileiro, no particular, é bastante abrangente e não deixa qualquer margem para dúvida acerca da competência da corte de contas para fiscalizar os contratos celebrados pela Administração Pública, em todos os níveis de governo.

Por sua vez, em Portugal, a competência para o tribunal de contas proceder a tal fiscalização também tem sede constitucional e infraconstitucional, a teor das disposições

\footnotetext{
${ }^{20}$ Art. 113. O controle das despesas decorrentes dos contratos e demais instrumentos regidos por esta Lei será feito pelo Tribunal de Contas competente, na forma da legislação pertinente, ficando os órgãos interessados da Administração responsáveis pela demonstração da legalidade e regularidade da despesa e execução, nos termos da Constituição e sem prejuízo do sistema de controle interno nela previsto. § 1 Qualquer licitante, contratado ou pessoa física ou jurídica poderá representar ao Tribunal de Contas ou aos órgãos integrantes do sistema de controle interno contra irregularidades na aplicação desta Lei, para os fins do disposto neste artigo. $§ 2^{o}$ Os Tribunais de Contas e os órgãos integrantes do sistema de controle interno poderão solicitar para exame, até o dia útil imediatamente anterior à data de recebimento das propostas, cópia de edital de licitação já publicado, obrigando-se os órgãos ou entidades da Administração interessada à adoção de medidas corretivas pertinentes que, em função desse exame, lhes forem determinadas. (Redação dada pela Lei $\mathrm{n}^{\circ} 8.883$, de 1994).

${ }^{21}$ Art. $1^{\circ}$. Ao Tribunal de Contas da União, órgão de controle externo, compete, nos termos da Constituição Federal e na forma estabelecida nesta Lei: [...] II - proceder, por iniciativa própria ou por solicitação do Congresso Nacional, de suas Casas ou das respectivas comissões, à fiscalização contábil, financeira, orçamentária, operacional e patrimonial das unidades dos poderes da União e das demais entidades referidas no inciso anterior; [...] $\S 1^{\circ}$ No julgamento de contas e na fiscalização que lhe compete, o Tribunal decidirá sobre a legalidade, de legitimidade e a economicidade dos atos de gestão e das despesas deles decorrentes, bem como sobre a aplicação de subvenções e a renúncia de receitas.
} 


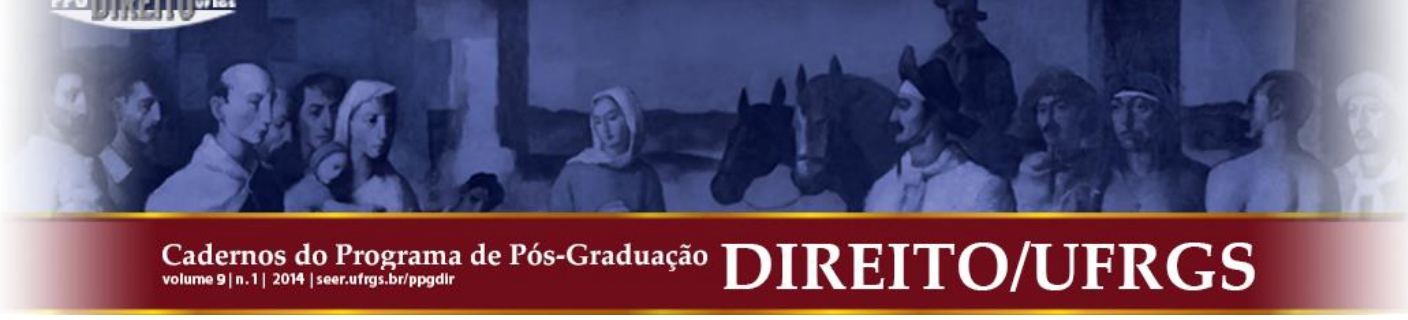

consubstanciadas no art. 214 da Constituição portuguesa ${ }^{22}$ e na Lei n $^{\circ}$ 98, de 26 de agosto de 1997, Lei de Organização e Processo do Tribunal de Contas, com as alterações posteriores ${ }^{23}$, sobretudo nos artigos $1^{\text {o24 }}$ e $5^{\circ}$.

Da mesma forma como a brasileira, a normatização portuguesa sobre a matéria não deixa margem para qualquer controvérsia sobre a competência do tribunal de contas para exercer a fiscalização financeira da contratação pública.

\section{MOMENTO DA FISCALIZAÇÃO FINANCEIRA DA CONTRATAÇÃO PÚBLICA: PRÉVIO, CONCOMITANTE E SUBSEQUENTE}

De modo geral, a doutrina pátria, especialmente de Hely Lopes Meireles (2002, p. 635), classifica o momento da atuação do tribunal de contas, que também se estende à fiscalização financeira da contratação pública, como: prévio, concomitante e subsequente.

Partindo-se, então, dessa classificação, tem-se que a fiscalização ou controle prévio, ainda designado de preventivo ou a priori, como é intuitivo pela denominação dada, é aquele que "antecede a conclusão ou operatividade do ato". Esse momento de efetivação da fiscalização condiciona a eficácia do ato à apreciação e validação pelo órgão de controle externo, que deve convalidar e previamente autorizar que o ato produza os efeitos desejados.

Já a fiscalização concomitante, também denominada de sucessiva, é aquela que ocorre pari passu ou de forma simultânea com o desenvolvimento das etapas de execução do ato, isto é, designa o controle que "acompanha a realização do ato para verificar a regularidade de sua formação, como, por exemplo, [...] a fiscalização de um contrato em andamento".

\footnotetext{
${ }^{22}$ Artigo 214. ${ }^{\circ}$ (Tribunal de Contas) 1. O Tribunal de Contas é o órgão supremo de fiscalização da legalidade das despesas públicas e de julgamento das contas que a lei mandar submeter-lhe, competindo-lhe, nomeadamente: a) Dar parecer sobre a Conta Geral do Estado, incluindo a da segurança social; b) Dar parecer sobre as contas das Regiões Autónomas dos Açores e da Madeira; c) Efectivar a responsabilidade por infracções financeiras, nos termos da lei; d) Exercer as demais competências que lhe forem atribuídas por lei. 2. O mandato do Presidente do Tribunal de Contas tem a duração de quatro anos, sem prejuízo do disposto na alínea $m$ do artigo $133 .^{\circ}$. 3. O Tribunal de Contas pode funcionar descentralizadamente, por secções regionais, nos termos da lei. 4. Nas Regiões Autónomas dos Açores e da Madeira há secções do Tribunal de Contas com competência plena em razão da matéria na respectiva região, nos termos da lei.

${ }^{23} 1$. $^{\mathrm{a}}$ alteração: Lei n. ${ }^{\mathrm{o}}$ 87-B/98, de 31 de Dezembro; $2{ }^{\mathrm{a}}$ alteração: Lei n. ${ }^{\circ}$ 1/2001, de 4 de Janeiro; 3. ${ }^{\mathrm{a}}$ alteração: Lei n. ${ }^{\circ}$ 55-B/2004, de 30 de Dezembro; 4. ${ }^{a}$ alteração: Lei n. ${ }^{\circ}$ 48/2006, de 29 de Agosto; 5. ${ }^{a}$ alteração: Lei n. ${ }^{\circ}$ 35/2007, de 13 de Agosto; 6. ${ }^{a}$ alteração: Lei n. ${ }^{\circ}$ 3-B/2010, de 28 de Abril; 7. alteração: Lei n. ${ }^{\circ}$ 61/2011, de 07 de Dezembro; $8 .{ }^{a}$ alteração: Lei n. ${ }^{\circ} 02 / 2012$, de 06 de Janeiro.

${ }^{24}$ Artigo $1 .^{\circ}$ Definição e jurisdição $1-\mathrm{O}$ Tribunal de Contas fiscaliza a legalidade e regularidade das receitas e das despesas públicas, aprecia a boa gestão financeira e efectiva responsabilidades por infracções financeiras.
} 


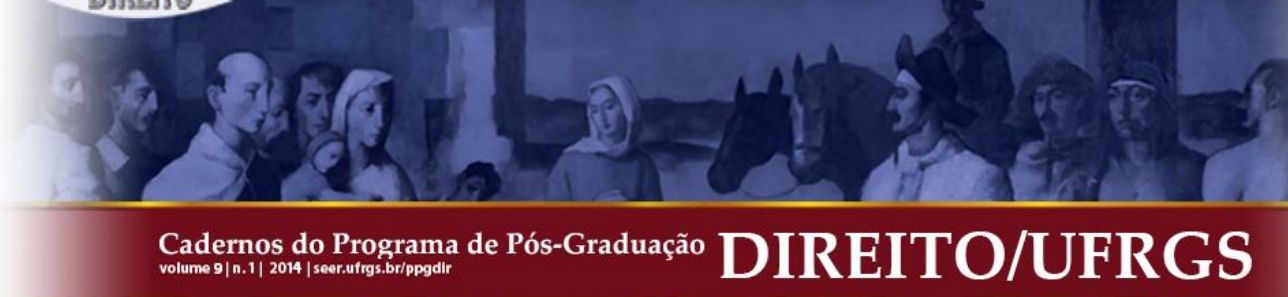

Lado outro, a fiscalização ou controle subsequente, ainda conhecido e designado como corretivo ou a posteriori, também como deixa transparecer as nomenclaturas utilizadas para designá-lo, é aquele que "se efetiva após a conclusão de ato controlado, visando a corrigir-lhe eventuais defeitos, declarar sua nulidade ou dar-lhe eficácia”.

A par das hipóteses existentes, compete à Constituição ou à lei infraconstitucional definir o momento da atuação do tribunal de contas, tendo em vista que, como demonstrado, a função de controle externo é constituída por plexo de atividades estritamente vinculado à lei.

\subsection{Momento adotado no Brasil}

Nessa linha de raciocínio, e de acordo com as atribuições outorgadas ao tribunal de contas na Constituição brasileira e em diplomas infraconstitucionais, a fiscalização financeira da contratação pública, no Brasil, em regra ou de forma usual, é subsequente ou a posteriori, já que ocorre depois da arrecadação da receita ou da realização da despesa pública.

No atual sistema jurídico brasileiro, não há previsão legal para a realização de controle prévio, isto é, em que a eficácia do ato fica condicionada à prévia apreciação e validação pelo órgão de controle externo, como exposto no item precedente, o qual foi adotado no Brasil pela Constituição de 1946 e vigorou até o advento da Carta de 1967.

Em virtude do sistema criado na Constituição de 1988 (art. 70) ${ }^{25}$, é possível inferir que a fiscalização prévia foi conferida ao sistema de controle interno de cada poder ou função do Estado, no qual se insere órgão de consultoria ou de assessoria jurídica. Isso porque o controle interno tem, entre outras finalidades, comprovar a legalidade e avaliar os resultados, quanto à eficácia e eficiência, da gestão orçamentária, financeira e patrimonial nos órgãos e entidades da administração federal, bem como da aplicação de recursos públicos por entidades de direito privado, apoiar o controle externo no exercício de sua missão institucional (art. 74). Entretanto, essa fiscalização prévia não condiciona a eficácia do ato à apreciação e validação pelo órgão de controle interno, para que produza os efeitos desejados.

Exemplificando, a minuta de edital de licitação, como também a do respectivo instrumento de contrato, deve ser previamente analisada pela assessoria jurídica, nos termos

\footnotetext{
25 Art. 70. A fiscalização contábil, financeira, orçamentária, operacional e patrimonial da União e das entidades da administração direta e indireta, quanto à legalidade, legitimidade, economicidade, aplicação das subvenções e renúncia de receitas, será exercida pelo Congresso Nacional, mediante controle externo, e pelo sistema de controle interno de cada Poder.
} 


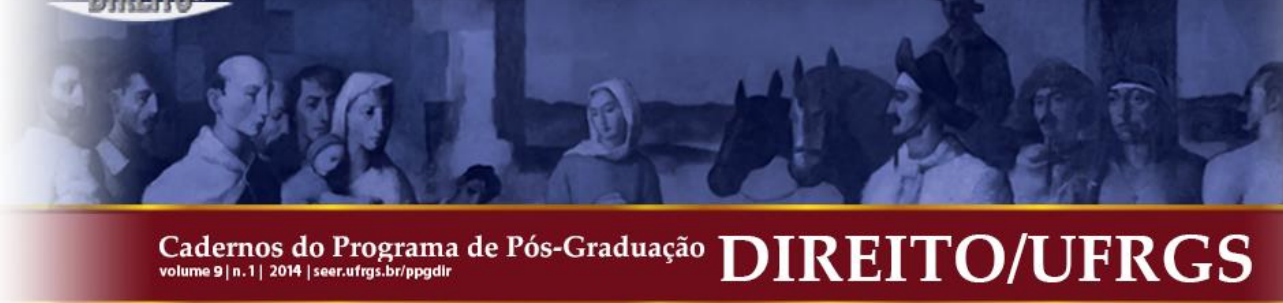

do parágrafo único do art. 38 da Lei no 8.666, de 1993. Mas, segundo Marçal Justen Filho (2012, pp. 594-595), a ausência de aprovação da assessoria jurídica, por si, não é causa de invalidade da licitação. O descumprimento desse comando legal não vicia o procedimento se o edital ou o contrato não apresentavam vício. Configurar-se-á apenas a responsabilidade funcional para os agentes que deixarem de atender à formalidade.

O mencionado autor salienta, entretanto, que a qualquer tempo pode-se, ou deve-se, determinar a audiência da assessoria jurídica, sendo que a constatação de ilegalidade poderá derivar a invalidação do certame ou o suprimento do vício, caso a manifestação da assessoria jurídica seja aceita pela autoridade superior.

Sobre essa temática, Marçal Justen Filho colaciona dois julgados do TCU. No Acórdão nº 1.337/2011, da relatoria do Ministro Walton Alencar Rodrigues, o Pleno do TCU decidiu que:

Da leitura do parágrafo único do art. 38 da Lei 8.666/1993 (examinar e aprovar), combinada com a do art. 11 da Lei Complementar 73/1993 (examinar prévia e conclusivamente), depreende-se que, para prática dos atos nele especificados o gestor depende de pronunciamento favorável da consultoria jurídica, revelando-se a aprovação verdadeiro ato administrativo. Sem ela, o ato ao qual adere é imperfeito.

Por sua vez, no Acórdão n 5.536/2010, da relatoria do Ministro Augusto Nardes, a Primeira Câmara do TCU assentou que:

\begin{abstract}
(...) o art. 38, parágrafo único, da Lei $\mathrm{n}^{\circ}$ 8.666/1993 dispõe claramente que as minutas de editais de licitação, bem como as dos contratos, acordos, convênios ou ajustes, devem ser previamente examinadas e aprovadas por assessoria jurídica da Administração. No presente caso, constatou-se que a análise e a provação da minuta do edital da Concorrência n ${ }^{\circ}$ AA 02/2008 foi feita pelo próprio Departamento de Licitações do BNDES, e não pelo seu Departamento Jurídico, em desacordo, portanto, com o estabelecido na referida lei. Além de infração a norma legal, tal procedimento configura a quebra de um dos princípios basilares do sistema de controle interno, derivado do princípio da moralidade administrativa, qual seja, o princípio da segregação de funções, segundo o qual as funções potencialmente conflituantes - autorização, aprovação, execução, controle e contabilização das operações - devem ser executadas por pessoas e setores independentes entre si, possibilitando a realização de verificação cruzada.
\end{abstract}

Impõe-se, portanto, que o sistema de controle interno seja devidamente estruturado no âmbito de cada unidade da federação brasileira para cumprir o relevante, necessário e indispensável papel que a Constituição lhe reservou, com a criação de quadro de pessoal efetivo e especializado, cujos servidores deverão ter, até, garantias legais para o exercício de 
suas atribuições. O autocontrole, com efeito, constitui salvaguarda para o erário e, por conseguinte, para o governante ou gestor compromissado com a boa e regular gestão dos bens e recursos públicos. E, como já sustentei alhures, parafraseando Alan Kardec, sem controle interno efetivo e atuante não há boa, regular e escorreita gestão pública.

Por outro lado, as atribuições consubstanciadas nos incisos IV, IX e X do art. 71 da Constituição republicana autorizam a fiscalização dos contratos administrativos de forma concomitante ou sucessiva. Isso porque conferem ao tribunal de contas competência para realizar inspeções e auditorias (inciso IV), ações de fiscalização que podem ser realizadas a qualquer momento, tudo dependerá do escopo da ação de fiscalização levada a efeito pelo órgão de controle externo. E, ainda, para assinar prazo, visando à adoção de providências necessárias ao cumprimento da lei, quando verificar ilegalidade (inciso IX), e ainda para sustar, se não atendido, a execução do ato impugnado (inciso X).

Materializando esses dispositivos constitucionais, o $\S 2^{\circ}$ do art. 113 da Lei $n^{\circ} 8.666$, de 1993, prevê hipótese de fiscalização concomitante, relativamente ao procedimento licitatório, ao dispor que "os Tribunais de Contas [...] poderão solicitar para exame, até o dia útil imediatamente anterior à data de recebimento das propostas, cópia do edital de licitação já publicado, obrigando-se os órgãos ou entidades da Administração interessada à adoção de medidas corretivas pertinentes que, em função desse exame, lhe forem determinadas".

Os efeitos do controle concomitante ou sucessivo são preventivos ou de prevenção como os do controle prévio. Entretanto, o controle concomitante ou sucessivo não se confunde com o controle prévio, nem mesmo em razão do referencial.

Isso porque, como já demonstrado, o controle prévio antecede a conclusão ou operatividade do ato. Esse momento de efetivação da fiscalização condiciona a prática do ato à apreciação e validação pelo órgão de controle externo, que deve convalidar e previamente autorizar que o ato seja praticado e produza os efeitos desejados. Diferentemente, na fiscalização concomitante ou sucessiva, o desiderato do órgão de controle é identificar irregularidades no curso da execução de ato ou procedimento da Administração Pública e fixar prazo para que a autoridade administrativa adote as medidas corretivas necessárias, a tempo e modo. Dessa forma, impede-se a concretização de atos ou procedimentos administrativos lesivos ao erário ou incompatíveis com as normas jurídicas de regência. $\mathrm{O}$ controle concomitante previsto no citado e transcrito dispositivo da Lei ${ }^{\circ}$ 8.666, de 1993, exemplifica bem isso, em virtude de seu efeito ser o de prevenir irregularidades em ato 
convocatório de certame licitatório, no contrato que dele se originar e, consequentemente, na realização da correspondente despesa pública.

Em temática relacionada a essa questão, o Supremo Tribunal Federal, no julgamento do RE 547063/RJ, entendeu que o tribunal de contas pode exigir o envio prévio de determinado edital de licitação para análise. No entanto, a exigência de que todos os editais sejam enviados previamente ao órgão de controle externo, feita por ato administrativo ou mesmo por lei estadual, é inconstitucional, porque apenas lei federal poderia criar essa obrigatoriedade, em razão da competência outorgada à União para legislar sobre normas gerais de licitação e contrato. Também no julgamento da ADI 916/MT, o STF julgou inconstitucional lei do Mato Grosso que determinava o envio prévio ao tribunal de contas, para registro, de todos os contratos celebrados pela Administração Pública estadual, por ferir a regra da simetria $(\mathrm{CF}$, art. 75), que não prevê como atribuição do tribunal de contas da União o controle preventivo e amplo de contratos.

Sem embargo do respeito que merece o excelso Pretório, a meu perceber, e diante de exame perfunctório, as decisões mencionadas são discutíveis, porque os pontos fulcrais das controvérsias nelas tratadas dizem respeito à competência material do tribunal de contas para realizar exame concomitante de edital de licitação e de contrato administrativo, ação de fiscalização plasmada nessa atribuição que, como visto, tem respaldo expresso na Constituição brasileira, e que, não raro, é confundida com o controle prévio.

Outro aspecto que ainda gera muita dúvida está relacionado à competência para a prática do ato de sustação do contrato administrativo, quando for verificada ilegalidade no procedimento que lhe deu origem ou na própria execução contratual.

Em princípio, o ato de sustação de contrato administrativo é, no âmbito da União, do Congresso Nacional, que deverá solicitar ao Executivo a adoção das medidas cabíveis para atingir tal desiderato. No entanto, se o Congresso Nacional não provocar o Executivo e se este, uma vez instado, não efetivar as medidas necessárias para anulação do contrato, em noventa dias, o tribunal de contas decidirá a respeito, conforme prescrevem os $\S \S 1^{\circ}$ e $2^{\circ}$ do art. 71 da Constituição brasileira. A contagem desse prazo deve iniciar-se da ciência das ilegalidades dada pela corte de contas, no caso, ao Congresso Nacional.

Dessa forma, a competência do tribunal de contas para sustar os efeitos de contrato administrativo irregular nasce da inércia do Congresso Nacional e do Poder Executivo no prazo constitucionalmente assinado. Nesse particular, Luciano Ferraz (2009, p. 144) adverte, 


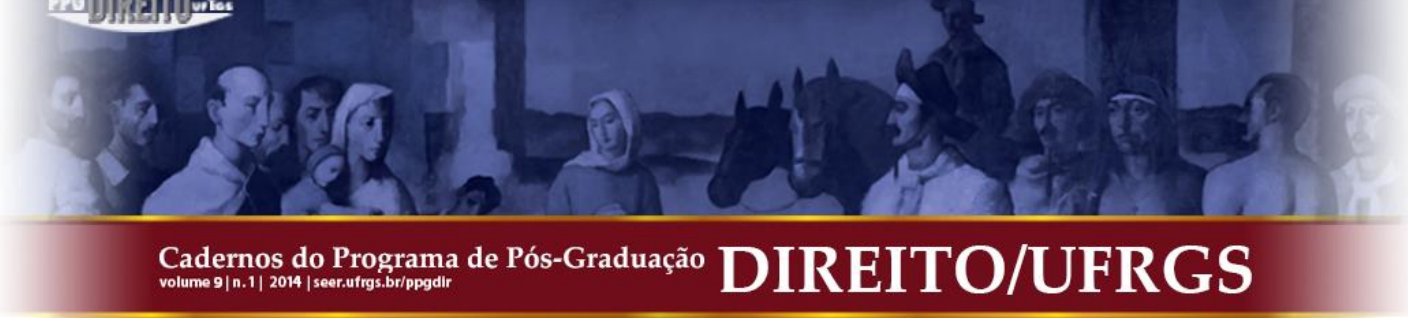

com propriedade, que "a anulação do ato ou do contrato se afigura ato de competência exclusiva da autoridade administrativa ou do Poder Judiciário".

Nada obstante, com fundamento nas disposições do inciso IX do art. 71 constitucional, o tribunal de contas tem competência para determinar, à autoridade competente, a anulação do contrato administrativo eivado de ilegalidade.

\subsection{Momento adotado em Portugal}

A legislação portuguesa - diferentemente da brasileira - é explícita quanto ao momento da atuação do tribunal de contas daquele país, porque traz a lume, de forma expressa e bem demarcada, quando a fiscalização financeira da contratação pública será prévia, concomitante ou sucessiva, senão vejamos.

O art. $5^{\circ}$ da Lei $n^{\circ}$ 98, de 1997, Lei de Organização e Processo do Tribunal de $\operatorname{Contas}^{26}$ (LOPTC), trata da fiscalização prévia, que é também chamada de "visto", da contratação pública.

Os contratos sujeitos à fiscalização prévia são aqueles previstos no art. 46 da LOPTC ${ }^{27}$, excluídos os mencionados no art. $47^{28}$, bem como aqueles de montante igual ou

\footnotetext{
${ }^{26}$ Artigo 5. ${ }^{\circ}$ Competência material essencial 1 - Compete, em especial, ao Tribunal de Contas: [...] c) Fiscalizar previamente a legalidade e o cabimento orçamental dos actos e contratos de qualquer natureza que sejam geradores de despesa ou representativos de quaisquer encargos e responsabilidades, directos ou indirectos, para as entidades referidas no.$^{\circ} 1$ e nas alíneas a), b) e c) do $n .^{\circ} 2$ do artigo $2 .^{\circ}$, bem como para as entidades, de qualquer natureza, criadas pelo Estado ou por quaisquer outras entidades públicas para desempenhar funções administrativas originariamente a cargo da Administração Pública, com encargos suportados por financiamento directo ou indirecto, incluindo a constituição de garantias, da entidade que os criou;

${ }^{27}$ Artigo 46. Incidência da fiscalização prévia 1 - Estão sujeitos à fiscalização prévia do Tribunal de Contas, nos termos da alínea $c$ ) do n. $^{\circ} 1$ do artigo $5 .^{\circ}: a$ ) Todos os actos de que resulte o aumento da dívida pública fundada dos serviços e fundos do Estado e das Regiões Autónomas com autonomia administrativa e financeira, e das demais entidades referidas nas alíneas $c$ ) a $e$ ) do n. $^{\circ} 1$ do artigo $2 .^{\circ}$, bem como os actos que modifiquem as condições gerais de empréstimos visados; $b$ ) Os contratos de obras públicas, aquisição de bens e serviços, bem como outras aquisições patrimoniais que impliquem despesa nos termos do artigo $48 .^{\circ}$, quando reduzidos a escrito por força da lei; c) As minutas dos contratos de valor igual ou superior ao fixado nas leis do Orçamento nos termos do artigo 48. ${ }^{\circ}$, cujos encargos, ou parte deles, tenham de ser satisfeitos no acto da sua celebração; $d$ ) Os actos ou contratos que formalizem modificações objetivas a contratos visados e que impliquem um agravamento dos respectivos encargos financeiros ou responsabilidades financeiras; e) Os actos ou contratos que formalizem modificações objetivas a contratos não visados que impliquem um agravamento dos respectivos encargos financeiros ou responsabilidades financeiras em valor superior ao previsto no artigo $48 .^{\circ}$.

${ }^{28}$ Artigo 47. ${ }^{\circ}$ Fiscalização prévia: isenções 1 - Excluem-se do disposto no artigo anterior: $a$ ) Os actos e contratos praticados ou celebrados pelas entidades referidas nas alíneas $a$ ), b) e $c$ ) do n.o 2 do artigo $2 .^{\circ}$, e que não se enquadrem na parte final da alínea $c$ ) do $n .^{\circ} 1$ do artigo $5 .^{\circ}$, de valor inferior a $€ 5000000$, bem como os actos do Governo e dos Governos Regionais que não determinem encargos orçamentais ou de tesouraria e se relacionem exclusivamente com a tutela e gestão dessas entidades; $b$ ) Os títulos definitivos dos contratos precedidos de minutas visadas; c) Os contratos de arrendamento, bem como os de fornecimento de água, gás e electricidade ou celebrados
} 


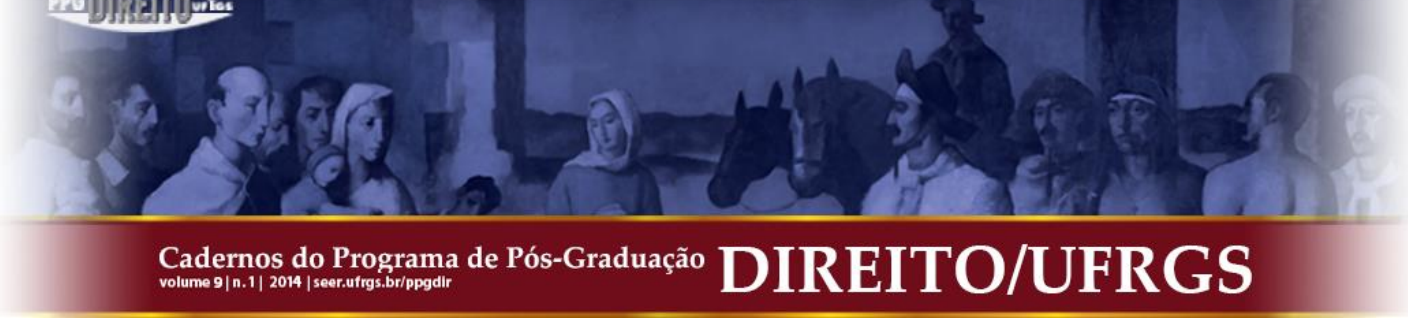

inferior ao previsto no art. 48 também da LOPTC, valor de alçada esse que, em 2013, corresponde a $€ 350.000$, o qual foi fixado pelo art. 145 da Lei $n^{\circ} 66-\mathrm{B}$, diploma legal que aprova o orçamento do Estado Português de 2013.

Lado outro, o art. $44^{29}$ da LOPTC dispõe sobre a finalidade e as causas que podem fundamentar a recusa do "visto".

Acerca da fiscalização prévia disciplinada na LOPTC, confira-se a seguinte passagem dos ensinamentos de José Luís Pinto Almeida:

\begin{abstract}
A fiscalização prévia consiste no exame da legalidade e regularidade em sentido restrito, segundo critérios de conformidade legal e regularidade financeira e contabilística, designadamente: (art. $44 .^{\circ}$, n..$^{\circ}$ s 1 e 2 ) - exame da legalidade (financeira); • verificação da cobertura orçamental dos respectivos encargos; • verificação, relativa aos instrumentos geradores de dívida pública, da conformação dos limites do endividamento e das respectivas finalidades. (ALMEIDA, 2008, p. 187)
\end{abstract}

Na mesma linha, é o magistério de Guilherme D’Oliveira Martins (2011, p. 12), quando conclui que "a fiscalização prévia permite uma análise independente e técnica da adequação da decisão às regras legais e financeiras em vigor, através da verificação do respeito pelos princípios e regras subjacentes ao processo de contratação".

Lídio de Magalhães (2006a, p. 206), mesmo reconhecendo que se possa discutir se este elenco é o mais apropriado, diz que a lista restrita de ilegalidades capazes de fundamentar

com empresas de limpeza, de segurança de instalações e de assistência técnica; $d$ ) Os actos ou contratos que, no âmbito de empreitadas de obras públicas já visadas, titulem a execução de trabalhos a mais ou de suprimento de erros e omissões, os quais ficam sujeitos a fiscalização concomitante e sucessiva; $e$ ) Os contratos destinados a estabelecer condições de recuperação de créditos do Estado; f) Contratos de aquisição de serviços celebrados com instituições sem fins lucrativos que tenham por objecto os serviços de saúde e de carácter social mencionados no anexo II-B da Directiva n. ${ }^{\circ}$ 2004/18/CE, do Parlamento Europeu e do Conselho, de 31 de Março, bem como os contratos de aquisição de serviços celebrados com instituições sem fins lucrativos que tenham por objecto os serviços de educação e formação profissional mencionados no referido anexo, que confiram certificação escolar ou certificação profissional; $g$ ) Outros actos, diplomas, despachos ou contratos já especialmente previstos na lei. 2 Os actos, contratos ou documentação referidos na alínea d) do número anterior são remetidos ao Tribunal de Contas no prazo de 60 dias a contar do início da sua execução.

${ }^{29}$ Artigo 44. ${ }^{\circ}$ Finalidade do visto. Fundamentos da recusa do visto 1 - A fiscalização prévia tem por fim verificar se os actos, contratos ou outros instrumentos geradores de despesa ou representativos de responsabilidades financeiras directas ou indirectas estão conforme às leis em vigor e se os respectivos encargos têm cabimento em verba orçamental própria. 2 - Nos instrumentos geradores de dívida pública, a fiscalização prévia tem por fim verificar, designadamente, a observância dos limites e sublimites de endividamento e as respectivas finalidades, estabelecidas pela Assembleia da República. 3 - Constitui fundamento da recusa do visto a desconformidade dos actos, contratos e demais instrumentos referidos com as leis em vigor que implique: $a$ ) Nulidade; $b$ ) Encargos sem cabimento em verba orçamental própria ou violação directa de normas financeiras; $c$ ) Ilegalidade que altere ou possa alterar o respectivo resultado financeiro. 4 - Nos casos previstos na alínea c) do número anterior, o Tribunal, em decisão fundamentada, pode conceder o visto e fazer recomendações aos serviços e organismos no sentido de suprir ou evitar no futuro tais ilegalidades. 


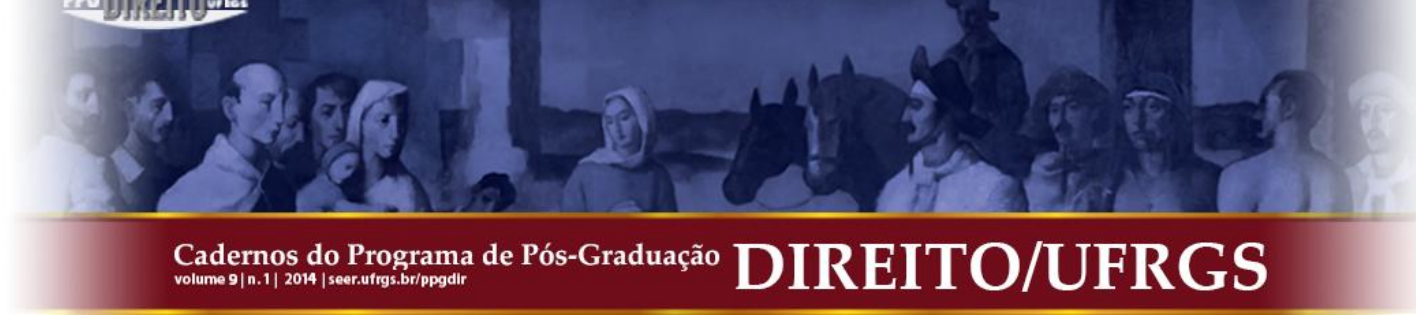

a recusa do "visto" - "ilegalidade geradora de nulidade; falta de cabimento; violação de norma financeira; ilegalidade susceptível de alterar o resultado financeiro" - constituiu importante avanço trazido pela Lei $\mathrm{n}^{\circ}$ 98, de 1997, considerando que, pelo sistema anteriormente vigente, em tese, até mera ilegalidade, por mais irrelevante que fosse, poderia levar à recusa do "visto".

A seu turno, o art. 45 da LOPTC ${ }^{30}$ estabelece os efeitos do "visto". De acordo com a redação do número 1 desse dispositivo, os contratos sujeitos à fiscalização prévia podem produzir todos os seus efeitos antes do "visto", à exceção dos financeiros. Já o número 3 também do art. 45 dispõe que os trabalhos realizados ou os bens ou serviços adquiridos depois da celebração do contrato e até à data da notificação da recusa do visto poderão ser pagos após esta notificação, desde que o respectivo valor não ultrapasse a programação contratualmente estabelecida para o mesmo período, desde que tenha sido feito o envio do respectivo processo ao tribunal de contas no prazo legal.

Da leitura e intelecção dos dispositivos legais indicados, e com fundamento nos ensinamentos doutrinários transcritos, extrai-se que a fiscalização prévia da contratação pública tem por objetivo o exame de conformidade ou regularidade legal, pois visa aferir o cumprimento de requisitos legais e orçamentários, sendo que o fundamento da recusa do "visto" é estritamente vinculado às hipóteses expressamente previstas em lei.

Além disso, pode-se concluir que a disposição contida no número 1 do art. 45 da LOPTC, de que os atos e contratos podem produzir todos os seus efeitos antes do "visto" ou da declaração de conformidade, embora excepcione os de caráter financeiro, como também a exceção contida no número 3 do mesmo dispositivo legal, retira da fiscalização prévia a sua principal característica ou mesmo a sua essência, que se caracteriza na impossibilidade de o ato ou contrato ter eficácia ou produzir efeitos antes da prévia convalidação e autorização do

\footnotetext{
30 Artigo $45 .^{\circ}$ Efeitos do visto 1 - Os actos, contratos e demais instrumentos sujeitos à fiscalização prévia do Tribunal de Contas podem produzir todos os seus efeitos antes do visto ou da declaração de conformidade, excepto quanto aos pagamentos a que derem causa e sem prejuízo do disposto nos números seguintes. 2 — Nos casos previstos no número anterior, a recusa do visto implica apenas ineficácia jurídica dos respectivos actos, contratos e demais instrumentos após a data da notificação da respectiva decisão aos serviços ou organismos interessados. 3 Os trabalhos realizados ou os bens ou serviços adquiridos após a celebração do contrato e até à data da notificação da recusa do visto poderão ser pagos após esta notificação, desde que o respectivo valor não ultrapasse a programação contratualmente estabelecida para o mesmo período. 4 - Os actos, contratos e demais instrumentos sujeitos à fiscalização prévia do Tribunal de Contas cujo valor seja superior a $€ 950000$ não produzem quaisquer efeitos antes do visto ou declaração de conformidade. 5 - O disposto no número anterior não é aplicável aos contratos celebrados na sequência de procedimento de ajuste directo por motivos de urgência imperiosa resultante de acontecimentos imprevisíveis pela entidade adjudicante, que não lhe sejam em caso algum imputáveis, e não possam ser cumpridos os prazos inerentes aos demais procedimentos previstos na lei.
} 


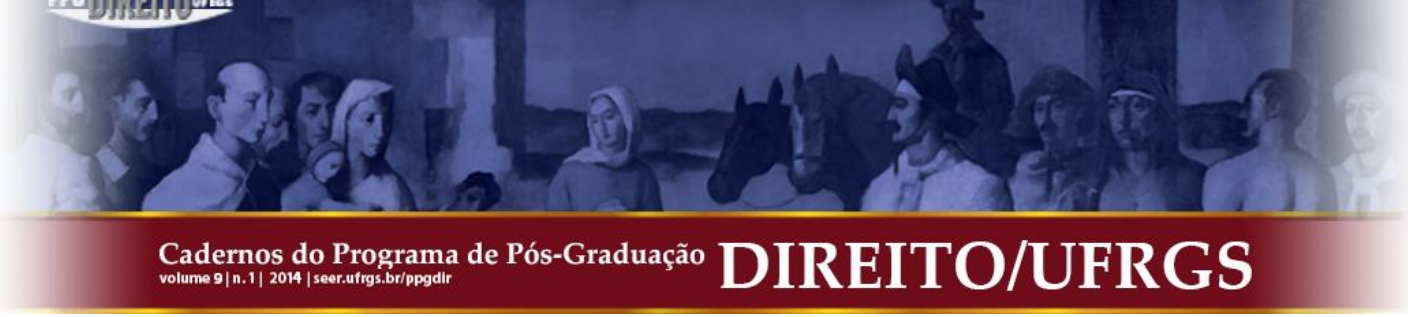

A Lei Orgânica e de Processos do Tribunal de Contas, nos termos de seus artigos 49 e $50^{31}$, também dispõe sobre a realização de fiscalização concomitante e sucessiva da contratação pública, a qual será feita nos contratos não sujeitos à fiscalização prévia, como também para verificação da execução de contratos visados.

Por sua vez, a fiscalização subsequente ou a posteriori materializa-se, sobretudo, na realização de auditorias para apreciar a legalidade, a economicidade, a eficiência e a eficácia dos órgãos e entidades sujeitos a controle do Tribunal de Contas, o que inclui, com efeito, toda a atividade contratual dos entes fiscalizados.

\section{CONSIDERAÇÕES FINAIS}

Ao final deste ensaio, fica patente que a fiscalização financeira da contratação pública, quanto ao momento adotado pelo tribunal de contas brasileiro e pela corte de contas portuguesa, apresenta, em linhas gerais, semelhanças, no que tange à adoção da fiscalização concomitante ou sucessiva e a subsequente ou a posteriori.

O que diferencia os sistemas analisados, no ponto enfocado neste trabalho, é que, em Portugal, adota-se a fiscalização prévia ou "visto", além da concomitante e da subsequente, nos casos previstos de forma expressa e bem delineados na lei daquele país. A legislação brasileira, embora não o faça expressamente e de maneira bem demarcada como a portuguesa,

\footnotetext{
${ }^{31}$ Artigo $49 .^{\circ}$ Fiscalização concomitante 1 - O Tribunal de Contas pode realizar fiscalização concomitante: $a$ ) Através de auditorias da $1 .{ }^{a}$ Secção aos procedimentos e actos administrativos que impliquem despesas de pessoal e aos contratos que não devam ser remetidos para fiscalização prévia por força da lei, bem como à execução de contratos visados; $b$ ) Através de auditorias da 2. ${ }^{a}$ Secção à actividade financeira exercida antes do encerramento da respectiva gerência. $2-\mathrm{Se}$, nos casos previstos no número anterior, se apurar a ilegalidade de procedimento pendente ou de acto ou contrato ainda não executado, deverá a entidade competente para autorizar a despesa ser notificada para remeter o referido acto ou contrato à fiscalização prévia e não lhe dar execução antes do visto, sob pena de responsabilidade financeira. 3 - Os relatórios de auditoria realizados nos termos dos números anteriores podem ser instrumentos de processo de verificação da respectiva conta ou servir de base a processo de efectivação de responsabilidades ou de multa.

Artigo $50 .^{\circ}$ Da fiscalização sucessiva em geral 1 - No âmbito da fiscalização sucessiva, o Tribunal de Contas verifica as contas das entidades previstas no artigo $2 .^{\circ}$, avalia os respectivos sistemas de controlo interno, aprecia a legalidade, economia, eficiência e eficácia da sua gestão financeira e assegura a fiscalização da comparticipação nacional nos recursos próprios comunitários e da aplicação dos recursos financeiros oriundos da União Europeia. 2 - No âmbito da fiscalização sucessiva da dívida pública directa do Estado, o Tribunal de Contas verifica, designadamente, se foram observados os limites de endividamento e demais condições gerais estabelecidos pela Assembleia da República em cada exercício orçamental. 3 - Os empréstimos e as operações financeiras de gestão da dívida pública directa, bem como os respectivos encargos, provenientes, nomeadamente, de amortizações de capital ou de pagamentos de juros, estão sujeitos à fiscalização sucessiva do Tribunal de Contas. $4-\mathrm{O}$ Instituto de Gestão do Crédito Público informará mensalmente o Tribunal de Contas sobre os empréstimos e as operações financeiras de gestão da dívida pública directa do Estado realizados nos termos previstos nesta lei.
} 


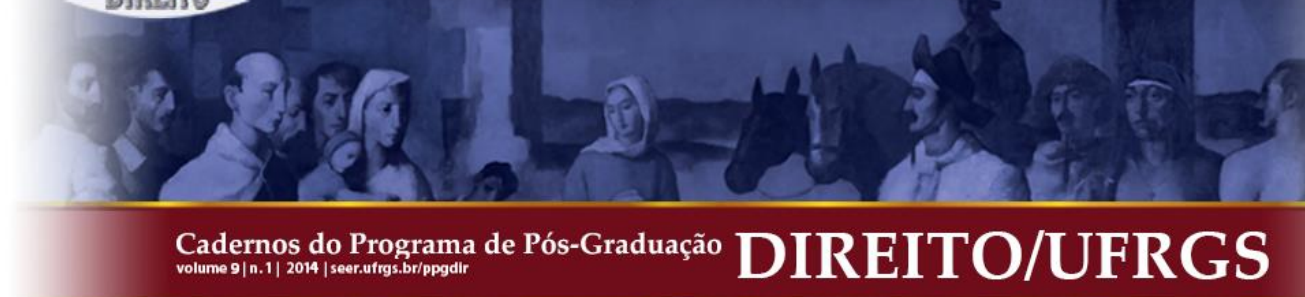

prevê somente os controles concomitante e subsequente, sendo que este constitui o momento usualmente adotado o Brasil.

Embora denominada de fiscalização prévia, essa ação do controle, em Portugal, perdeu a principal característica ou a essência, na maioria dos casos previstos na legislação portuguesa, tendo em vista que o ato ou contrato pode produzir efeitos, antes da manifestação do tribunal de contas português, excetuadas algumas hipóteses, como a do exame das minutas dos contratos cujos encargos, ou parte deles, tenham de ser satisfeitos no ato da sua celebração, as quais, em rigor, configuram ou representam o controle prévio.

No Brasil, com o advento da Carta de 1988, e tendo em vista o sistema de fiscalização engendrado no caput do art. 70, é possível afirmar que o controle prévio passou a ser atribuído ao sistema de controle interno de cada poder ou função do Estado, em razão do feixe de atribuições que foi cometido ao autocontrole no texto constitucional. Entretanto, sem condicionar a eficácia do ato à apreciação e validação pelo órgão de controle interno, para que produza os efeitos desejados. Urge, pois, que os governantes brasileiros efetivem a indispensável e necessária estruturação do sistema de controle interno no âmbito de cada unidade da federação brasileira, em razão da imprescindibilidade do autocontrole para a boa, regular e escorreita gestão dos bens e recursos públicos, o qual, entre outras finalidades, deve apoiar o controle externo no exercício de sua missão institucional.

A meu perceber, o sistema brasileiro é mais adequado às modernas práticas de administração pública ou de governança, sobretudo se considerarmos que o controle prévio ou "visto" pelo tribunal de contas adotado em Portugal, mesmo existindo a figura do visto tácito, pode constituir-se em mais um entrave ou elemento de atraso para a contratação daqueles bens ou serviços mais urgentes para atendimento às demandas da sociedade, que clama, cada vez mais, por serviços públicos eficientes, oportunos e de qualidade.

Os tribunais de contas brasileiro e português, sem descurar, por óbvio, das demais matérias sujeitas ao crivo do controle externo, devem continuar pertinazes no aprimoramento das ações de fiscalização da contratação pública, que se apresenta como uma das principais fontes de despesa pública no Brasil e em Portugal. Esses órgãos, com efeito, devem dar foco às ações de fiscalização de cunho preventivo, que inclui a realização de orientação permanente aos jurisdicionados, com vistas a sanar, a tempo e modo, ou até impedir a concretização de atos e procedimentos administrativos lesivos ao erário ou incompatíveis com as normas jurídicas. É que, nessa quadra, a prevenção - sobretudo, em se tratando da gestão 


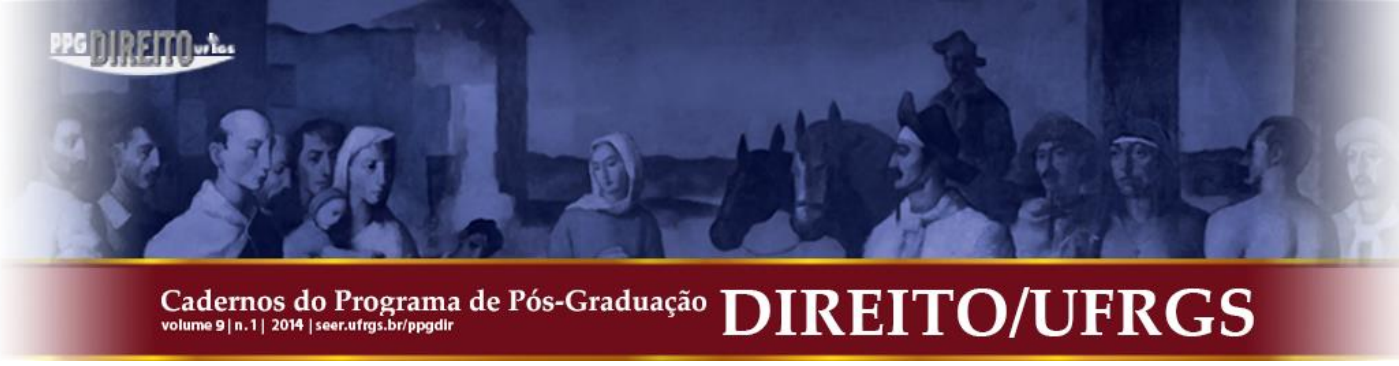

de recursos públicos, cada vez mais escassos frente à sempre crescente demanda da sociedade -, apresenta-se como sinônimo de economia, eficiência e qualidade na Administração Pública.

\section{REFERÊNCIAS}

ALMEIDA, José Luís Pinto. Fiscalização prévia, concomitante e sucessiva no quadro das competências do tribunal de contas. Revista de Finanças Públicas e Direito Fiscal, Lisboa, ano $1, \mathrm{n}^{\circ} 3$, pp. 179-205, 2008.

ARAÚJO, Florivaldo Dutra de. Negociação coletiva dos servidores públicos. Belo Horizonte: Fórum, 2011.

BANDEIRA DE MELLO, Celso Antônio. O enquadramento constitucional do tribunal de contas. In: FREITAS, Ney José de (Coord.). Tribunais de contas aspectos polêmicos: estudos em homenagem ao Conselheiro João Féder. Belo Horizonte: Fórum, 2009.

BRITTO, Carlos Ayres. O regime constitucional dos tribunais de contas. In: SOUZA, Alfredo José de et al. (Coord.). O novo tribunal de contas: órgão protetor dos direitos fundamentais. 3. ed. rev. e ampl. Belo Horizonte: Fórum, 2005.

CANOTILHO, J. J. Gomes. Direito constitucional e teoria da constituição. 7. ed. 6. reimpressão. Coimbra: Almedina, 2003.

CHEVALLIER, Jacques. O estado pós-moderno. Tradução de Marçal Justen Filho. Belo Horizonte: Fórum, 2009.

DECOMAIN, Pedro Roberto. Tribunais de contas no brasil. São Paulo: Dialética, 2006.

FERNANDES, Cidalina Leonor. O sistema de controlo interno nos municípios portugueses: o caso da câmara municipal de ansião. Relatório de estágio apresentado no curso de mestrado em economia da Faculdade de Economia da Universidade de Coimbra, setembro de 2010. Disponível em <https://estudogeral.sib.uc.pt/bitstream/10316/14614/1/Relat\%C3\%B3rio\%20de\%20Est\%C3 \%A1gio\%20-\%20Cidalina\%20Fernandes.pdf>. Acessado em: 28 mar. 2014. 


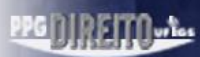

OLIVEIRA, Gustavo Justino de; SCHWANKA, Cristiane. A administração consensual como a nova face da administração pública no séc. XX: fundamentos dogmáticos, formas de expressão $e$ instrumentos de ação. 2008. Disponível em: <http://www.conpedi.org.br/manaus/arquivos/anais/salvador/gustavo_henrique_justino_de_ol iveira.pdf $>$. Acessado em: 19 jun. 2013.

ORTIZ, Gaspar Ariño. El enigma del contrato administrativo. Revista de Administración Pública, Madrid, $\mathrm{n}^{\mathrm{o}}$ 172, enero-abril de 2007. Disponível em:<http://www.larioja.org/upload/documents/684866_RAP_172-2007.

enigma_del_contrato.pdf $>$. Acessado em: 29/5/2013.

ROPPO, Enzo. O contrato. Trad. de Ana Coimbra e M. Januário C. Gomes. Coimbra: Almedina, 2009.

SALGADO, Joaquim Carlos. A ideia de justiça em Hegel. Belo Horizonte: Loyola, 1996.

SALGADO, Karine. História e estado de direito. Revista do Tribunal de Contas, Belo Horizonte, vol. 71, n. 2, abril/junho de 2009.

TAVARES, José F. F. Os contratos públicos e a sua fiscalização pelo tribunal de contas. In: GONÇALVES, Pedro Costa (Org.). Estudos da contratação pública. Vol. I, Coimbra: Coimbra Editora, 2008.

Almedina, 2007.

O tribunal de contas: do visto em especial. Edição digital. Coimbra:

VALA, Márcia; BARROS, Manuel Freire. O controlo financeiro externo da contratação pública. Revista do Tribunal de Contas, Lisboa, nº 27, janeiro-junho de 1997.

Submissão: $12 / 01 / 2014$

Aceito para Publicação: 04/04/2014 